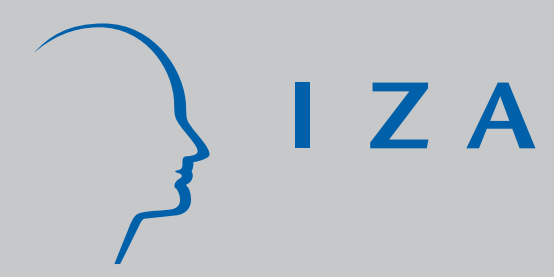

IZA DP No. 860

Timing and Flexibility of Housework and Men and Women's Wages

J ens Bonke

Nabanita Datta Gupta

Nina Smith

August 2003 


\title{
Timing and Flexibility of Housework and Men and Women's Wages
}

\author{
Jens Bonke \\ Danish National Institute of Social Research \\ Nabanita Datta Gupta \\ CIM and Aarhus School of Business \\ Nina Smith \\ CIM, Aarhus School of Business, DIW Berlin \\ and IZA Bonn \\ Discussion Paper No. 860
August 2003
}

IZA

P.O. Box 7240

D-53072 Bonn

Germany

Tel.: +49-228-3894-0

Fax: +49-228-3894-210

Email: iza@iza.org

This Discussion Paper is issued within the framework of IZA's research area The Future of Labor. Any opinions expressed here are those of the author(s) and not those of the institute. Research disseminated by IZA may include views on policy, but the institute itself takes no institutional policy positions.

The Institute for the Study of Labor (IZA) in Bonn is a local and virtual international research center and a place of communication between science, politics and business. IZA is an independent, nonprofit limited liability company (Gesellschaft mit beschränkter Haftung) supported by Deutsche Post World Net. The center is associated with the University of Bonn and offers a stimulating research environment through its research networks, research support, and visitors and doctoral programs. IZA engages in (i) original and internationally competitive research in all fields of labor economics, (ii) development of policy concepts, and (iii) dissemination of research results and concepts to the interested public. The current research program deals with (1) mobility and flexibility of labor, (2) internationalization of labor markets, (3) welfare state and labor market, (4) labor markets in transition countries, (5) the future of labor, (6) evaluation of labor market policies and projects and (7) general labor economics.

IZA Discussion Papers often represent preliminary work and are circulated to encourage discussion. Citation of such a paper should account for its provisional character. A revised version may be available on the IZA website (www.iza.org) or directly from the author. 
IZA Discussion Paper No. 860

August 2003

\section{ABSTRACT \\ Timing and Flexibility of Housework and Men and Women's Wages*}

This paper analyses the effect of housework on men and women's wages in Denmark by estimating quantile regressions on Danish time use survey data from 1987, merged to register information on hourly wages and other labour market variables for each of the years 1987-1991. We find, as in U.S. studies, that housework has negative effects on the wages of women and positive effects on the wages of men, except at the high end of the conditional wage distribution. At the 90th quantile, housework has a positive effect on the wages of women and a negative effect on the wages of men, and in fact, high-wage men receive the largest wage penalty of doing housework. Timing and flexibility of housework turn out to be more important than the level of housework, and women, particularly at the high end of the conditional wage distribution, who time their housework immediately before or after market work or engage in home tasks that require contiguous blocks of time are significantly penalized in terms of lower wages. These findings are even stronger for married and cohabiting couples and for workers on fixed time schedules as opposed to workers with flexible time schedules which are part of a bargain with the employer.

JEL Classification: D13, J16

Keywords: $\quad$ housework, time use, flexibility, timing, wages

Corresponding author:

Nina Smith

Department of Economics

Aarhus School of Business

Prismet

Silkeborgvej 2

8000 Aarhus C

Denmark

Tel.: +458948 6421

Fax: +4589486197

Email: nina@asb.dk

\footnotetext{
* The project has received financial support from the Danish Social Research Council (FREJA). Thanks to Daniel Hamermesh, Jean Young, Joyce Jacobsen, Leslie Stratton and participants at the IZA conference, May 2002 and May 2003 and the EALE conference 2002, for many helpful comments. Astrid Würtz has done most of the computational work.
} 


\section{Introduction}

Despite the fact that Danish women's participation in the labour market has increased rapidly since the 1970s, the division of work within the household still remains unequal. Currently in the $25-45$ age group, almost $84 \%$ of women participate in the labour market, compared to $90 \%$ of men, but Danish time use data from 1987 show that men on working weekdays still spend less time on housework compared to women in couple households: 81 minutes a day for men and 171 minutes for women. Though these figures have become more equal over time, the different roles of men and women within the household may still be expected to influence the amount of effort and achievement on their jobs. For the US, Hersch (1991a,b), Hersch and Stratton (1997, 2000), Noonan (2001) and Stratton (2001) have documented that the amount of time spent on housework has a negative effect on wages. For Canada, Phipps et al. (2001) also find that the amount of housework has a negative effect on the earnings capacity of women.

The effect of housework activities may vary across the wage distribution. Especially for men and women in higher ranking positions holding demanding jobs, it may be impossible to combine the job with a large amount of housework or inflexible housework tasks. The very compressed wage structures in the Scandinavian countries and high tax levels imply that the price of market services (domestic help, restaurant visits etc.) is very high, and that the market for private services may not even exist in the Scandinavian countries, contrary to the US which has a fairly well functioning market for most household services. This may induce even high-income families in Scandinavia to undertake more housework and do-it-yourself work compared to families for instance in the US. However, it may not only be the amount of housework which influences the labour market performance of men and women. Also the timing and flexibility of housework may have negative effects on earnings and the career, especially at the higher end of the qualification distribution and thus this may be one explanation of an increasing unexplained gender wage gap at the upper end of the wage distribution in Denmark and Sweden (Datta Gupta et al. (2003), Albrecht et al. (2003)).

Earlier studies, mainly from the US, have documented that housework has a different effect on male and female wages and that the type of housework also matters, see Hersch and Stratton (2000), Noonan (2001) and Stratton (2001). However, none of these previous studies have incorporated timing and flexibility aspects of housework and their effects on wages. When 
housework is done during the day may be just as important for wages as the amount of housework. ${ }^{1}$ Housework that is timed relatively close to market work hours may have more punitive effects on wages than housework that is timed farther away from market work hours because individuals may need to interrupt their work hours in order to undertake such activities or experience higher levels of stress or fatigue while trying to balance the conflicting needs of the job and the household and these factors lower productivity and hence wages. In this paper, we examine the wage effects of having flexibility with respect to one's housework and test whether or not these effects are different for men and women. Most previous studies have generally constrained the effect of housework to be the same at all points in the wage distribution. We estimate a traditional human capital model of hourly wages augmented by different aspects of housework responsibilities, including timing and flexibility as well as job characteristics but in contrast to the previous literature, we fully characterize the houseworkwage relationship along the conditional wage distribution by using a quantile regression approach. Unlike some of the previous studies in this area (Hersch and Stratton $(1997,2000)$ ), we do not model the endogeneity of housework. Clearly, housework (both the amount and timing) may be potentially endogenous to wages as those with higher wages typically do less housework and more market work and this biases the coefficient of housework in a wage regression which treats housework as exogeneous. But, we were unable to find suitable instruments for housework hours in the present data we have available (see Section 5). Therefore, we concentrate here on introducing the notion of flexibility and timing of housework and testing their effects at different points along the conditional wage distribution.

The analysis is based on merged register and survey data, i.e. the Danish 1987 Time Use Survey (TUS) for information on household activities and market work and administrative registers for information on wages and labour market characteristics for the period 1987-1991 for the individuals included in TUS.

In Section 2, we sketch a theoretical model which states a relationship between market wages, the amount of housework and the time flexibility devoted to market work and housework and

\footnotetext{
${ }^{1}$ There are a number of other questions in which the issue of timing can be important. For instance, Hamermesh (2003) analyses the demand of temporal variety or its absence, routine, and finds that economic incentives are important in decisions of timing of daily activities.
} 
discusses the implications of this model. In Section 3, the time use and register data applied in the study are described, and Section 4 presents some descriptive analyses on Danish time use patterns. In Section 5, an empirical model is presented. The results from estimations are presented in Section 6, and finally, Section 7 offers a conclusion.

\section{Theoretical Model}

In one of his seminal papers, Becker (1985) discusses the importance of the allocation of home time and the resources and effort devoted to market work: "Earnings in some jobs are highly responsive to changes in the input of energy, while earnings in others are more responsive to changes in the amount of time. ... Persons devoting much time to effort-intensive household activities like child care would economize on their use of energy by seeking jobs that are not effort intensive, and conversely for persons who devote most of their household time to leisure and other time-intensive activities", Becker (1985, p. S49). The allocation of time within the household is assumed to be determined by comparative advantage. Women are assumed to be more productive in certain types of housework, especially child production and child care. A key assumption in the Becker model is that the individual allocates a given amount of time and effort on different activities, for instance housework, leisure time and market work. Becker shows that given these assumptions, the individual will devote less effort to the job, the more housework is done at home, and this explains that usually women earn lower market wages than men.

The Becker model has been criticised because of the assumption of a given amount of effort. It could be that individuals, who derive utility from their job and devote a lot of effort to the job, also devote more effort at home. Or the other way around, that some individuals who spend many hours on housework activities, spend few hours on passive leisure activities, for instance watching television, may devote more effort to their job, see Bielby and Bielby (1988) and Stratton (2001). Thus, if the amount of effort is not exogenously given, the implications of the Becker model become less unambiguous. Since the causality in the Becker model is that housework affects effort which affects wage rates, one should expect that controlling for effort, the direct effect of housework on wages might disappear. However, empirical studies which combine information on effort variables, housework and wage rates indicate that including information on effort does not reduce the significance of housework, see Stratton (2001). 
Instead of focussing on effort, we turn our attention to the importance of timing and flexibility of housework in this study. Many housework activities have to be done at regular points in time each day. If there are babies or young children in the family, a number of tasks such as preparing food, eating, bathing the children, preparing the children for school etc. are time inflexible tasks which have to be done each day at fairly fixed points in time. The same holds for activities like picking up children from day care centres, sport activities etc., which may imply that the parent has to leave the job earlier in the afternoon. If employees are required to be present at meetings in the morning and late in the afternoon, this may have consequences for job and career. Other types of household activities are much more time flexible such as do-it-yourself work and can even be done on weekends. Therefore, it is important to focus on the flexibility and the timing of the housework activities and not just on the amount of housework. If women more often, due to tradition, comparative advantage or other reasons, undertake daily routine tasks which need be done at regular points in time while men do housework tasks which can be relegated to weekends or late in the evening, women will tend to be less flexible with respect to their market jobs and have lower potential for career advancement than men.

The importance of timing and flexibility in household activities depends on how easy it is to substitute between the time of household members and market services. Despite young children being time consuming and implying time inflexibility, parents are in principle able to substitute part of the care. The same holds for other household activities. For example, sending children to child care centres during working hours or hiring a 'nanny' are possible strategies as are visiting restaurants, employing a cleaner to take care of daily cleaning tasks etc. However, the substitution depends among other things on the prices of services bought in the market. A compressed wage structure and a high indirect tax level imply high prices of most household services in Denmark. Thus, many households cannot afford much substitution for their housework time, and high-income families who can afford these services often face a thin and not well-functioning service market. ${ }^{2}$ Due to these reasons, we expect that timing and flexibility of daily housework tasks like child care, food preparing, cleaning etc. are important factors

\footnotetext{
${ }^{2}$ The typical marginal income tax even on low-skilled workers exceeds $50 \%$, VAT is $25 \%$, and thus the tax wedge is high. In an empirical analysis based on German and US data, Schettkat (2003) demonstrates that a much larger tax wedge in Germany compared to the US partly explains why the Germans undertake much more housework and do-it-yourself work and less market work compared to US citizens.
} 
impacting career development, especially in families with younger children where the needs of children are particularly time inflexible.

It is not an easy task to define flexibility, since the notion of flexibility may have a number of dimensions to it such as variability or stability over time, uncertainty with respect to future work requirements etc.. For instance, temporal stability with respect to the timing of housework activities may imply that the individual has a high degree of certainty with respect to when she is able to undertake market activities. On the other hand, temporal stability can also imply that she is inflexible and for instance has to leave the job early in the afternoon each day in order to pick up children. Further, the concept of flexibility depends on whether flexibility is viewed from the perspective of the employer or the employees. Flexibility from the employer's perspective will typically mean inflexibility from the employee's perspective. ${ }^{3}$ According to these considerations, we come up with the following definition for flexibility as: the ease with which an individual can alter the timing of daily work or housework according to the needs of the employer (flexibility devoted to market work) or the family (flexibility devoted to non-market activities). Thus, the amount of flexibility that the individual has at his or her disposal, is in part dependent on the nature and type of work or housework, in part on family background characteristics, in part on job characteristics and in part on unobserved factors such as tastes for work. We assume that each individual can allocate a given amount of flexibility to market work, housework or to leisure activities, personal care, sleep etc. Thus, besides allocating a fixed amount of time each day to market work, housework and leisure, the person has to decide how flexible he or she wants to be at the job and how much flexibility, he or she reserves for the family, household tasks and leisure time. Thus flexibility which is devoted to the job or to housework can be thought of as an additional 'input' which increases the value of each hour spent as either working in the market or at home.

Assume, in line with the Becker model, that the individual can distribute the total time allocation,

\footnotetext{
${ }^{3}$ However, in some cases the employer and the employee may bargain more or less explicitly about the timing and flexibility of market work, for instance by having flex-time working schedules where the worker him- or herself is allowed to decide when to come to work in the morning or when to leave the job, typically with some restrictions, or the worker may be allowed to work at home (distance work) during part of the working time. If there exists this type of (implicit) contract between the employer and the employees, the negative trade-off between flexibility at work and flexibility at home may be loosened, for instance as is the case in most academic jobs.
} 
$t$, to three activities, market work $(m)$ and two types of housework activities $(j=1,2)$ where activity 1 is much more flexibility intensive than activity 2 , i.e. activity 1 demands to a much larger extent than activity 2 that the activity is undertaken at given points in time during the day. For instance activity 1 may be routine tasks like food preparing and cleaning, while activity 2 is do-it-yourself work. ${ }^{4}$

$$
t_{1}+t_{2}+t_{m}=t
$$

Further, parallel to the time constraint, the individual is assumed to have a given amount of flexibility (normalized to 1) which can be allocated to the three activities,

$$
F_{1}+F_{2}+F_{m}=1
$$

We assume that the 'output' or the 'value' $\left(I_{j}\right)$ of each of the housework activities and market work depends on the human capital acquired for each of these production processes, $H C_{j}(j=$ $m, 1,2)$. Further, the 'value' depends on the time (hours) and flexibility devoted to the activity $\left(t_{j}\right.$ and $\left.F_{j}\right)$. For simplicity, we assume a Cobb-Douglas production function for the value of time and flexibility devoted to the housework and market work activities:

$$
I_{j}=H C_{j} F_{j}^{\sigma j} t_{j}^{1-\sigma j} \quad(j=m, 1,2)
$$

where $\sigma_{j}$ is the flexibility intensity related to activity $j$. Denoting $f_{j}=F_{j} / t_{j}$, i.e. the flexibility per hour which can be shown to be a constant because of the Cobb-Douglas assumption, one gets the hourly 'wage rate' in activity $j$ as

$$
w_{j}=H C_{j} f_{j}^{o j} \quad(j=m, 1,2) .
$$

The size of $\sigma_{j}$ is crucial when determining the endogenous variable $f_{j}$. We assume $\sigma_{j}<1$, for $j=m, 1,2$, and further that $\sigma_{1}>\sigma_{2}$ and $\sigma_{m}>\sigma_{2}$. Thus, non-market activity 1 and market work are assumed to be more demanding than non-market activity 2 with respect to flexibility. The

\footnotetext{
${ }^{4}$ We abstract away from the leisure choice which is irrelevant for the purposes of our model.
} 
ranking between non-market activity 1 and market work depends on which types of activities and jobs are considered. If the job is a very demanding job with much responsibility, $\sigma_{m}$ is large (though smaller than 1 in order to secure that more hours of work always imply a higher market income, $I_{j}$ ) while less demanding jobs are represented by lower values of $\sigma_{m}$. Analogously, if there are young children in the household, household activities may be relatively time inflexible. In the Becker model, $\sigma_{j}$ is treated as exogenously given, but in a more general model the variables reflecting the flexibility intensities should be considered endogenous. The flexibility intensity of non-market activities may be determined by endogenous fertility, and the flexibility intensity of market work by endogenous sector and occupational choice.

By introducing a traditional home production function approach for the two household goods $(j=1,2)$, see Appendix A, and maximizing utility defined in these two goods subject to income, time and flexibility constraints, one can derive the demand and supply functions for market goods and services $\left(x_{j}\right)$, time devoted to the market and housework activities $\left(t_{j}\right)$, and flexibility devoted to market and housework activities $\left(f_{j}\right)$ as functions of endowment of human capital in different activities $\left(H C_{j}\right)$, flexibility intensities, $\sigma_{j}$, prices and non-wage income. Focussing only on market wages, the observed market wage may be written as

$$
w_{m}=w_{m}\left(H C_{m}, \sigma_{m}, f_{m}\left(\sigma_{1}, \sigma_{2}, \sigma_{m}, Z\right)\right)
$$

where $\mathrm{Z}$ is a vector of the additional variables which determine flexibility $\left(f_{m}\right)$ devoted to market work. Parallel to the Becker model, see Becker (1985), one can show that the amount of flexibility devoted to the job is a negative function of the flexibility intensity demanded in the house work activities:

(4) $\frac{\partial f_{m}}{\partial \sigma_{j}}=-\frac{\sigma_{m}}{\sigma_{m}\left(1-\sigma_{m}\right) \sigma_{j}^{2}}<0$,

i.e. the relative flexibility devoted to the job is larger, the smaller is $\sigma_{j}$, i.e. the less time flexibility demanding the housework activities. For a given value of $\sigma_{m}$, i.e. for a given type of job, a person who undertakes flexibility intensive non-market activities, $\sigma_{j}$ close to 1 , will devote lower flexibility to the job than a person who engages in non-market activities with a low value 
of $\sigma_{j}$. This effect is larger, the more demanding the job is, i.e. the larger $\sigma_{m}$ is.

\section{Data}

Our main data source, the Danish Time Use Survey, 1987, which is a simple random sample of about 3600 adult Danish people aged 16-76, contains demographic and socio-economic information on the current work behaviour on the labour market for all persons, i.e. the amount of hours including overtime and hours in supplementary jobs in a normal working week. The sample used in this study includes employed individuals who filled out a time-diary during a working weekday or during a weekend day. For the sample with information on a working weekday, we exclude individuals with less than $1 \frac{1}{2}$ hours of continuous work during the diary day. For individuals observed on a weekend, we apply the general restriction that they must be employed, but place no restriction on the hours typically worked on a weekend day. This leaves us with a sample of 2102 employed individuals, 1356 observed on working weekdays and 746 individuals observed during a weekend day.

In the time-diary the respondents record the main activity (i.e. work, sleep, recreation, housework etc.) in 15-minute intervals for the full 24-hour period prior to the interview day. In addition to market work, ten different categories of housework and several categories of leisure activities are identified in the data summing up to 39 activities, see Appendix B.

The time use survey is matched to administrative income-tax registers and registers on labour market attachment for each of the years 1987-1991. Thus, we are able to trace career development for a period of 4 years after the survey was collected. The register data include information on the person interviewed in 1987 and the spouse if it is a couple household. For each of the years 1987-1991, we have information on annual earnings and other income variables, actual labour market experience, sector (public or private), occupational position, education, number and age of children, and information on spousal income and labour market variables. If the interview person changes civil status (and spouse) and/or acquires more children, this is registered, and information on new spouse or child is included in the data. In Appendix C, sample means for the years 1987 and 1991 are shown for the variables included in the estimations. 
The register information allows us to calculate hourly wage rates by dividing annual earnings by annual employed hours. Thus, our earnings measure suffers from the traditional weakness attributed to this measure, i.e. measurement error in hours is transmitted to the wage variable. The wage rate variable (which is measured in 1987 prices, DKK) includes overtime payments but excludes pension payments not included in registered annual earnings. The Danish pension payments rules change during the period, and these changes affect the level of measured wage rates. Therefore in the empirical model presented below, we include year-specific indicators in order to catch these changes in the overall level of the observed wage rates.

\section{The Amount and Timing of Housework Activities}

Table 1 shows the number of minutes spent on different activities during the day distributed by quartiles of the male and female wage distribution. The upper figures show hours on working weekdays (Monday-Friday) and the lower figures show hours on weekend days (SaturdaySunday). On working weekdays, men in the upper quartile of the wage distribution on average spent 8.9 hours (536 minutes) on paid work, while corresponding women spent about 6.6 hours (396 minutes). For men, there is a clear pattern, in that the higher the position in the wage distribution, the more market work, whereas for women, we do not observe this tendency. Women in the upper wage quartile do not have more paid work on average than women in the second and third quartile. Looking at housework, women in the upper quartile do slightly less housework, about 2.7 hours (164 minutes) compared to the lower quartiles (3 hours in lower quartile) on working weekdays. ${ }^{5}$ For men, we do not observe this pattern. Men in the lowest quartile work slightly fewer minutes than men in the other quartiles.

Looking at the different housework activities, there is a clear gender division of work. Women tend to engage in food preparation and cleaning activities while men do more do-it-yourself activities, particularly in the weekends. ${ }^{6}$ This raw empirical evidence confirms the hypothesis

\footnotetext{
${ }^{5}$ In the study by Gronau and Hamermesh (2001), it is found that the amount of housework decreases by educational level for married women in all countries included in their study. Interestingly, the only exception from this pattern is Sweden, where the most educated women do more housework than women with a medium level of education.

${ }^{6}$ The time spent on (direct) caring for children is surprisingly small, partly due to the fact that both parents and nonparents are included in the sample, see for instance Gronau and Hamermesh (2001) where the time allocation in 6 countries (Australia, Israel, the Netherlands, Sweden, the US, West Germany) is shown. Danish men and women seem to spend much less time on their children compared to these countries. Another reason is that parents typically record a lot of activities done simultaneously with child care in other categories than child care (as housework,
} 
Table 1. Average number of minutes spent on different activities during a working weekday (Monday-Friday: upper figures) and a weekend day (Saturday-Sunday: lower figures). 1987').

Men

Women

Quartile in male wage distribution 1987

Quartile in female wage distribution 1987

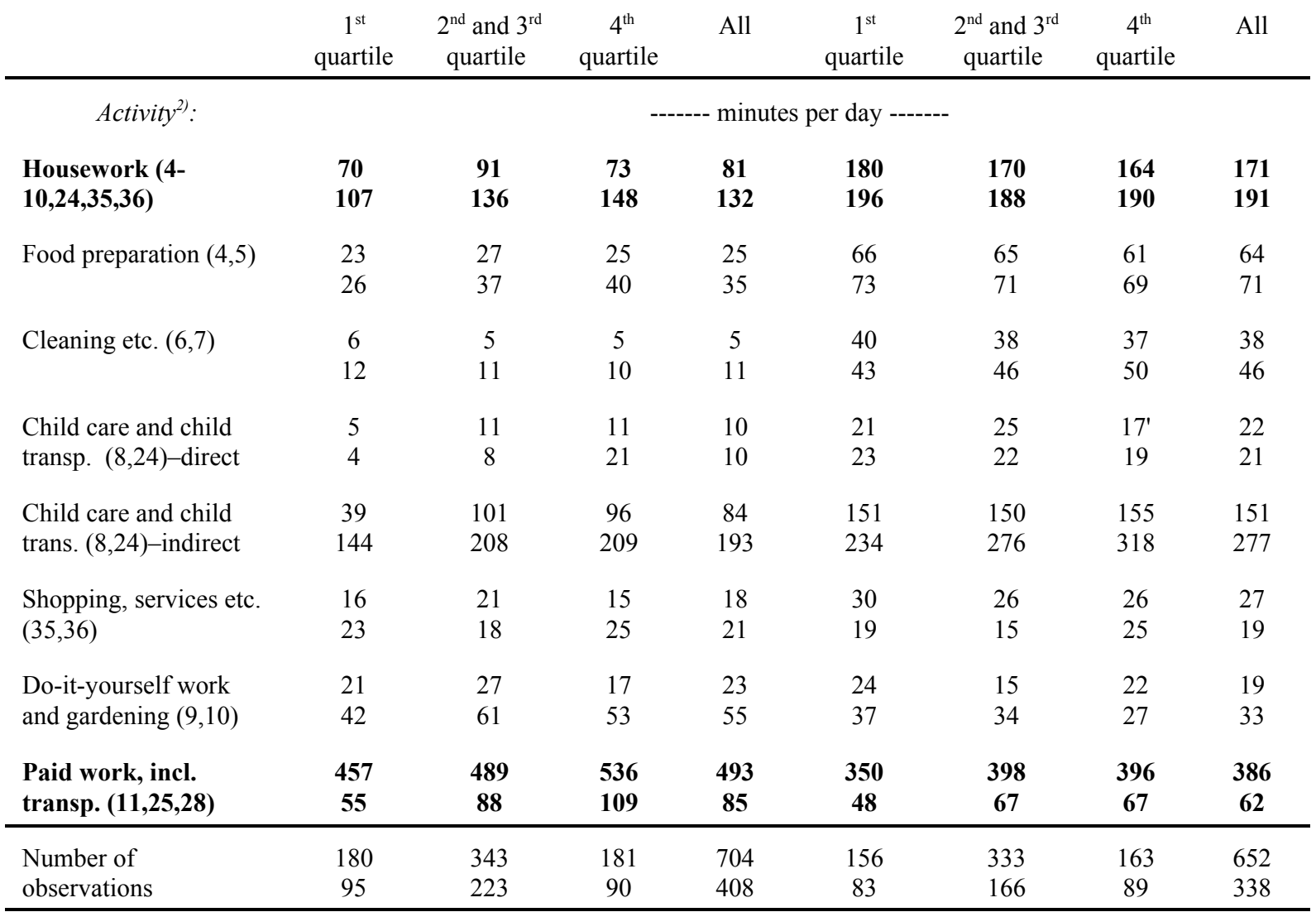

1) Only individuals who were employed during the survey week are included.

2) The numbers given in parentheses refer to activity types, see Appendix B.

3) Child care and child transportation--indirect is not included in total housework.

that women tend to have more routine activities which are rather inflexible in the sense that they have to be done each day, while men tend to have more time-flexible activities. During the weekend days, women and men increase their housework activity, especially men and women in the upper wage quartile. Women, mainly in the upper wage quartile, seem to do the cleaning work during the weekend, while men do a lot of do-it-yourself work and gardening during the weekend.

leisure or other). As the survey contains explicit information on whom in the family is present when the different activities are performed, we are able to identify a much larger amount of indirect child care (child care performed as the secondary activity) as shown in Table 2 . The definition of housework used in this paper includes only direct child care. However, in Table 6, we test the robustness of our results to an expanded definition of housework in which time spent on both direct and indirect child care is included. 
In order to look more closely at the timing of the housework activities and the market work, we calculate the distribution of time spent on market work, housework and other activities (sleep, personal care, leisure time) at each quarter of the day. Figure 1 shows these distributions for men and women on working weekdays and weekend days. The housework profile is clearly double peaked: During the morning (about 10 a.m.) and about dinner time (18 p.m.) a relatively large proportion of women's time (30-40\%) is spent on housework, both at weekends and on working weekdays. For men, the pattern is different. They spend only about $10 \%$ of their time on housework during the morning on working weekdays, but on weekends it is mainly during the morning that men work at home. During working weekdays, men tend to do more market work than women early in the day and late in the afternoon, while women on average have more housework early in the morning and late in the afternoon.

The observed pattern in Figure 1 may confirm, that women are less flexible at the job since they tend to time more market work late in the morning and early in the afternoon (when the children are probably at school or at the day care centre) compared to men. However, we do not know whether the persons observed would have been able to time their market work and housework differently, and whether it is the timing of housework or market work which determines the allocation of time during the day. Instead in Table 2 below we try, by combining the type of activity and timing information from the time diaries, to identify different indicators of the flexibility of housework and market work activities.

According to Table 2 below, women do more housework before they go to work and more housework just after they have left their job than men do. On average, women spend 37 minutes doing housework before they start at their job (including travel), and 100 minutes after they leave the job. For men the same figures are 14 and 44 minutes. Men have longer breaks between their job and their housework, and a much larger proportion of men than women do not undertake any type of housework before their paid work ( $65 \%$ of men and $33 \%$ of women). The majority of housework is done after the paid work has finished, but $52 \%$ of the males in the sample and $22 \%$ of the females do not undertake any housework when they arrive home after their paid work. 
Figure 1. Timing of housework, market work and other activities during the day. Men and women who were employed during the survey week. Weekends and working weekdays. 1987. (Signature: Dark Blue/Grey= Market Work, Medium Blue/Grey=Housework, White=Others)

\section{Women Weekend Day}

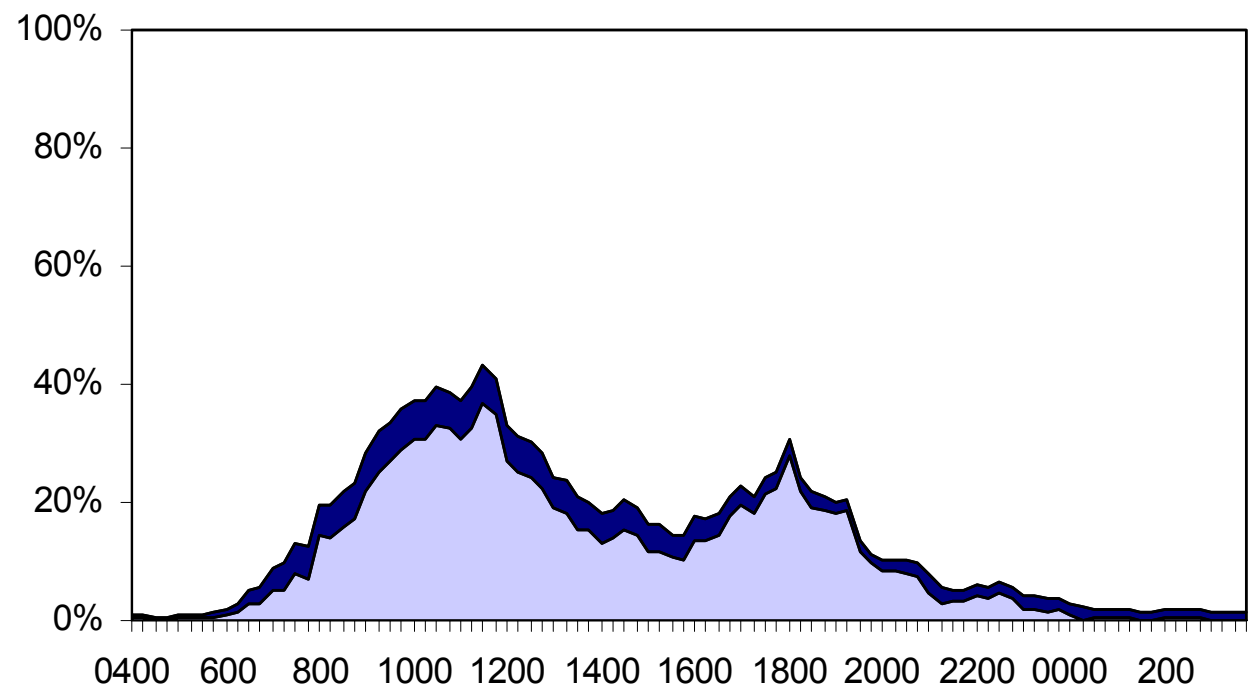

Men Weekend Day

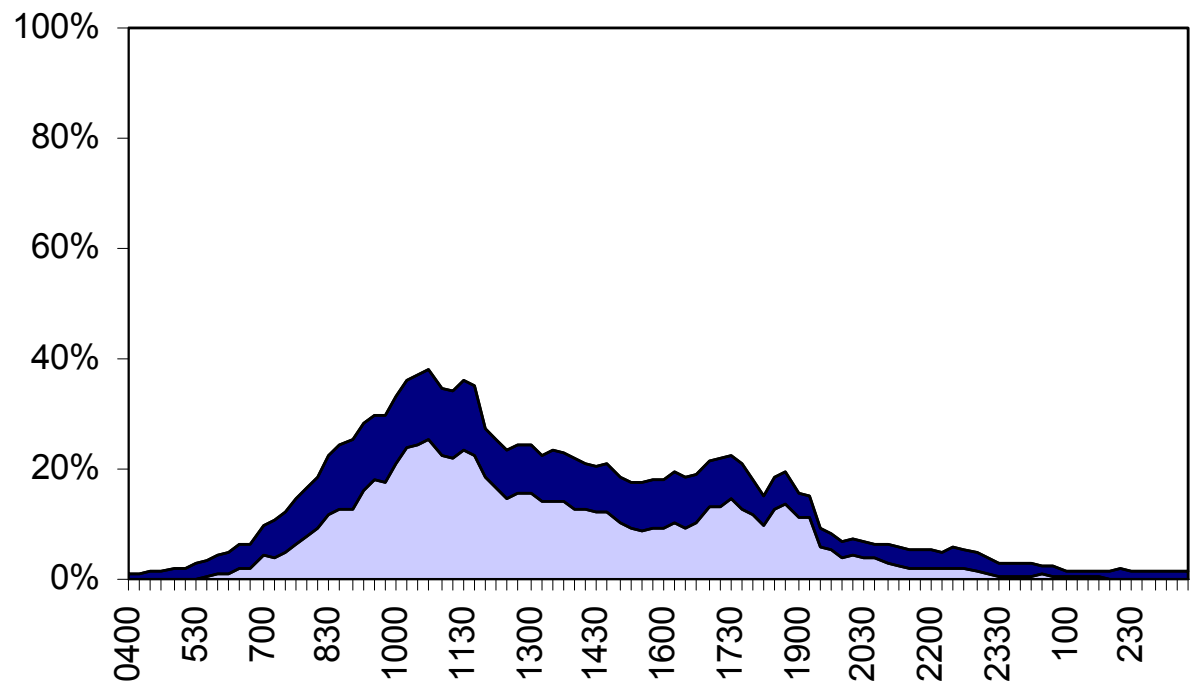


Women Working Weekday

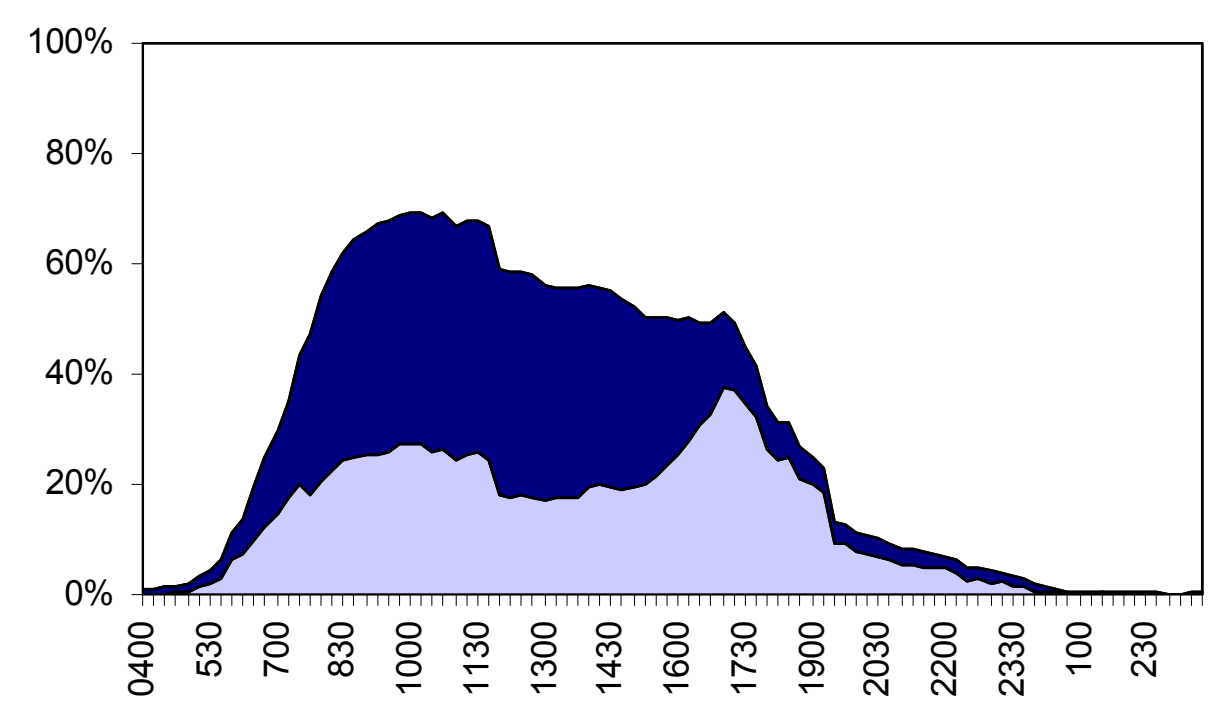

Men Working Weekday

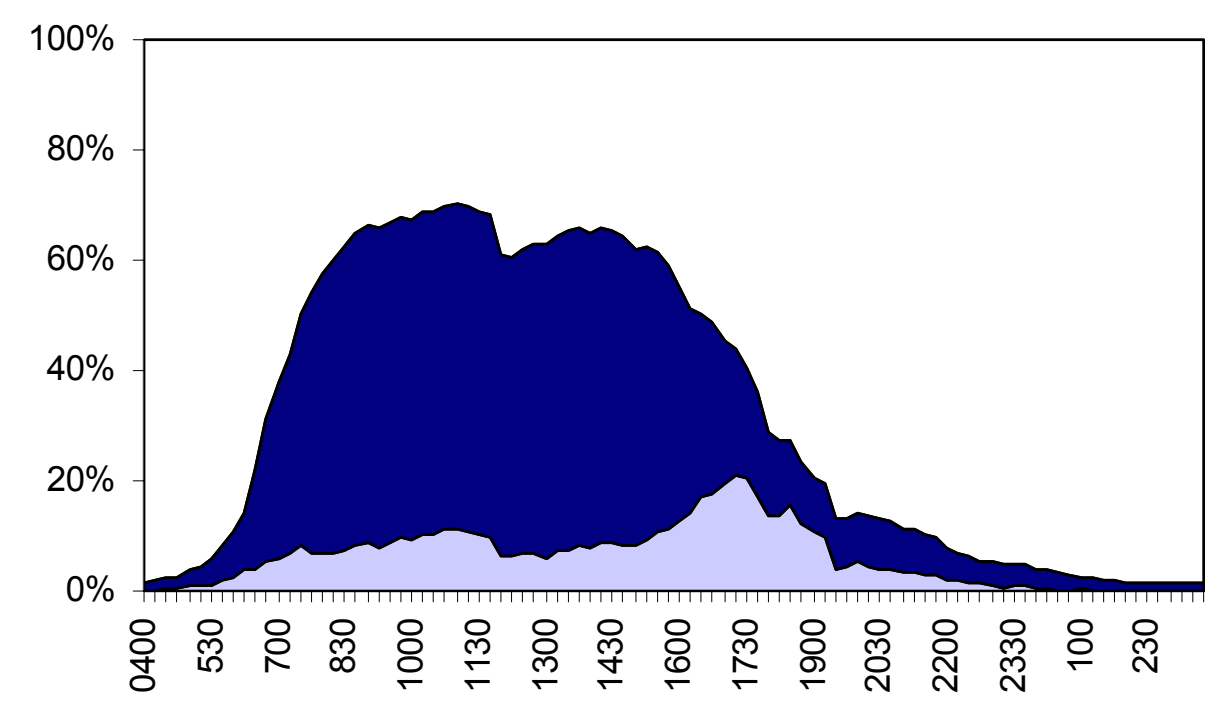


Table 2. Housework before and after market work and breaks between housework and market work during a working weekday (Monday-Friday). 1987.

\begin{tabular}{|c|c|c|c|c|}
\hline & \multicolumn{2}{|c|}{ Men } & \multicolumn{2}{|c|}{ Women } \\
\hline & mean (min.) & st.dev & mean (min.) & st.dev \\
\hline Housework before market work ${ }^{1)}$ & 14 & 34 & 37 & 56 \\
\hline Housework after market work ${ }^{1)}$ & 44 & 66 & 100 & 87 \\
\hline $\begin{array}{l}\text { Morning break, conditional on doing housework } \\
\text { before market work }{ }^{2)}\end{array}$ & 42 & 55 & 34 & 35 \\
\hline \multirow{3}{*}{$\begin{array}{l}\text { Afternoon break, conditional on doing housework } \\
\text { after market work }^{3)}\end{array}$} & 66 & 79 & 48 & 68 \\
\hline & \multicolumn{2}{|c|}{ Men } & \multicolumn{2}{|c|}{ Women } \\
\hline & $\begin{array}{l}\text { Before } \\
\text { (Morning) }\end{array}$ & $\begin{array}{c}\text { After } \\
\text { (Afternoon) }\end{array}$ & $\begin{array}{l}\text { Before } \\
\text { (Morning) }\end{array}$ & $\begin{array}{c}\text { After } \\
\text { (Afternoon) }\end{array}$ \\
\hline No housework before or after market work & $65 \%$ & $52 \%$ & $33 \%$ & $22 \%$ \\
\hline $0<$ break $<=30 \mathrm{~min}$ & $22 \%$ & $26 \%$ & $47 \%$ & $54 \%$ \\
\hline $30 \min <$ break $<=60 \mathrm{~min}$ & $10 \%$ & $9 \%$ & $15 \%$ & $11 \%$ \\
\hline $60 \min <$ break $<=90 \mathrm{~min}$ & $2 \%$ & $6 \%$ & $3 \%$ & $6 \%$ \\
\hline Break $>90$ min & $1 \%$ & $7 \%$ & $2 \%$ & $7 \%$ \\
\hline All & $100 \%$ & $100 \%$ & $100 \%$ & $100 \%$ \\
\hline
\end{tabular}

1. Paid work is restricted to a period of more than 90 minutes including transportation time.

2. Time between household work and first period of paid work (paid work restricted to a period of more than 90 minutes of work).

3. Time between last period of paid work (paid work restricted to a period of more than 90 minutes of work) and housework.

This evidence gives some indirect empirical support of our hypothesis that women tend to be more inflexible in their jobs because they have more housework tasks which need to be done at inflexible points in time. In fact, much casual evidence support these findings that women more than men hurry home after work to pick up children or do the shopping. In Denmark shopping hours are more limited and most stores close by 5:30 or 6:00pm while daycare centres close at $5 \mathrm{pm}$ and as it is typically women who are responsible for shopping and picking up the children, the effect of these restricted hours may reduce women's flexibility more than men's. ${ }^{7}$

\footnotetext{
${ }^{7}$ A study of the lifting of shopping hours constraint in the Netherlands shows that women are most affected by the relaxation of such laws and increase their market hours the most following the change, both due to their employment in the retailing sector but also due to their increased work hours in other sectors (Jacobsen and Koorenman, 2003).
} 


\section{Empirical Model}

According to the theoretical model above, the hourly wage rate observed is given by $w_{m}=$ $w_{m}\left(H C_{m}, \sigma_{m}, f_{m}\left(\sigma_{1}, \sigma_{2}, \sigma_{m}, Z\right)\right)$. Thus, we estimate a human capital wage function, where we successively include more detailed information on housework activities $(H W)$ and job-specific and household-specific factors which capture $\sigma_{j}$, i.e. explain flexibility-intensity aspects $(F)$. The wage functions are estimated by quantile regression methods (Koenker \& Bassett (1978), Buchinsky (1998)) where we specify the $\theta$ th quantile of the conditional wage distribution given $X$ and housework variables $H W$ as a linear function of the covariates:

$$
Q_{\theta}\left(\operatorname{Ln} W_{i t} \mid X_{i p} H W_{i}\right)=\beta_{0}(\theta)+X_{i t} \beta(\theta)+H W_{i} \gamma^{1}(\theta)+F_{i t} \gamma^{2}(\theta), \quad \theta=(0.1,0.5,0.9)
$$

where $Q_{\theta}\left(\epsilon_{i t} \mid X_{i}, H W_{i}, F_{i t}\right)=0, X_{i t}$ is a vector of (time varying) explanatory variables included in traditional human capital functions, $H W_{i}$ is a vector of time use variables from the year 1987 , $F_{i t}$ is a vector of time varying variables determining flexibility intensity, and $\beta(\theta), \gamma^{l}(\theta)$ and $\gamma^{2}(\theta)$ are parameter vectors to be estimated. The subscripts $i=1, . . \mathrm{n}$ and $t=1987, \ldots, 1991$ index the individual and time, respectively, and $\epsilon_{i t}$ is an error component. The use of quantile regressions allows the marginal effect of housework to vary across the quantiles of the conditional wage distribution consistent with the evidence suggested by the raw data in Table 1. Standard errors are obtained through 200 bootstrap repetitions, based on Koenker and Basset (1978) algorithms. As individuals are observed repeatedly over time, the data should in principle be corrected for time-constant individual effects. However, a simple differencing technique cannot be applied here, because differencing the quantiles of the conditional wage distribution would yield the effect of additional $H W$, for example on the $\theta$ h quantile of the conditional distribution of withinperson wage differences, rather than the effect of $H W$ on the conditional wage distribution, that is, the quantile estimates obtained from differenced data are not equivalent to quantile estimates from data on levels (Arias et al. (2002)). In a survey article on the quantile method, Koenker and Hallock (JEP, forthcoming), also caution against additive random effects as the quantile of convolutions of random variables is likely to be highly intractable. Thus as of yet, quantile methods have not been applied to panel data, although one study by Chay (1995) applies minimum distance methods to unrestricted quantile regressions of several cross sections.

Another consideration is that time use is observed only in 1987. We assume that the 1987 time 
allocation gives a reliable picture of the allocation of time for the 4 consecutive years after, or at least we assume that the allocation of time in 1987 had effects on the consecutive wage development. Thus, we analyse how time allocation affects wages in the medium run. However, note that this means that each person's time use measure appears multiple times in the quantile regression equation, leading to the random disturbance in the regression being correlated within person groups. As pointed out by Moulton (1990), the consequence may be that standard errors are biased downwards (and t-statistics biased upwards) leading to spurious conclusions about the significance of the aggregate time-use measure in the wage equation. While a test of the importance of this correlation and correction of standard errors could be attempted in an OLS wage regression, the quantile method is not yet as well developed to take account of this problem However, we devise an informal test of the significance of this problem below. ${ }^{8}$ Further, in Table 6 , Model 3b, we explore the sensitivity of our findings to this assumption when we replicate the analysis on the sub-sample of individuals who remain married or cohabiting throughout the sample period, as for these individuals, we expect little change in housework duties to occur over the sample period.

Yet another problem is that the housework variables may be endogenous. Those with higher market wages may do fewer hours' housework and more market work, and therefore we may obtain biased estimates of the wage effects of housework, see Hersch and Stratton (1997, 2000). Therefore, we have experimented with instrumentation of the housework variables. As instruments we used a number of register variables for the years 1986 and 1987 (number of rooms in house, number and age of children, number of adults in household, own unemployment experience during the year, different characteristics of the spouse, household income and the

\footnotetext{
${ }^{8}$ As an informal test, we have estimated the basic model (Model 1, see below, including the housework variable) on two different samples: Sample 1 contained one third of the observations (about 635 individuals) observed repeatedly in the years 1987, 1989 and 1991. Sample 2 contained the pooled sample of the first third of the individuals observed in 1987, the second third of the individuals observed in 1989 and the last third of the individuals observed in 1991, i.e. a pooled sample consisting of 3 independent cross-section samples observed in either 1987, 1989 or 1991 (about 1300 distinct individuals). When we compare the estimated standard errors from the estimated models on these two samples, we do not find any systematic differences in the size of the standard errors. For instance, the estimated standard error on the coefficient of the amount of housework at the $10^{\text {th }}$ percentile is -0.017 (0.016) for women (men) in Sample 1, while the same figure in Sample 2 is -0.007 (0.010). For none of the estimated variables, do we find large deviations between the results from the two samples. We take this as (imprecise) evidence that our estimated standard errors are not greatly underestimated, despite estimating our model on a pooled sample of highly dependent cross sections.
} 
square value of all these variables). ${ }^{9}$ However, our tests on the validity of our instruments in all the different specifications we tried came out negatively, i.e. we were not able to find valid instruments according to the test procedure described in Bound et al. (1995). ${ }^{10}$

\section{Results}

\section{A. Amount of Housework}

The results from estimating simple quantile regression wage functions including the amount of housework are shown in Tables 3-4. First, the results from estimating a basic human capital model, Model 1, including the total amount of housework are shown in Table 3. In this model, as well as in the following models which extend the basic model, we pool the samples of men and women and interact all human capital variables (which include education, experience and paid work hours), housework variables, family, sector and occupational variables by the gender variable, i.e. estimate gender-specific coefficients to these variables. Year indicators, the regional indicator variable and the constant term are not interacted with gender. Further, we include an indicator variable 'woman', in order to get an estimate on how much the constant term for women deviates from the male constant term. Since we estimate the coefficients of the pooled conditional wage distribution, the 'woman' indicator is interpreted as a partial measure of the 'unexplained' gender wage gap in the model concerned. ${ }^{11}$ In the next step, we extend the basic model by adding job and household characteristics variables which are supposed to capture

\footnotetext{
${ }^{9}$ Following Arias et al. (2002), we use a two-stage quantile regression estimator, in which the first stage is described above, where we project endogeneous HW on the space spanned by the instruments which are assumed (and tested) to be uncorrelated with the error term. In the second stage we perform quantile regression of log wages on the projected HW obtained in the previous stage and on the other exogeneous regressors. The two-stage quantile estimator has been shown to be asymptotically consistent in previous studies. The correction of the standard errors requires the estimation of a sparsity function using non-parametric techniques or bootstrapped versions of the same.
}

\footnotetext{
${ }^{10}$ Hersch and Stratton (1997) also test for endogeneity of housework, and they conclude that they cannot reject that the amount of male housework is exogenous to their model, while they reject exogeneity for female housework.

${ }^{11}$ By estimating gender-specific coefficients on the human capital variables, we implicitly assume away the part of the unexplained gap that is due to differences in returns to human capital variables. Thus, the coefficient on the woman indicator should be regarded as a lower bound on the true unexplained gap. Indeed, the "gender gap" found in the data are smaller than those found in previous studies for Denmark, $+.8 \%$ at the $10^{\text {th }}$ quantile, $-.01 \%$ at the $50^{\text {th }}$ quantile and $-12 \%$ at the $90^{\text {th }}$ quantile. Moreover, these "gaps" turn positive or disappear when market work hours are included in the wage regression. We are hesitant to conclude that gender differences in paid work hours account for the wage gap in Denmark, in part because including paid work hours in the wage regression may introduce potential endogeneity and in part because, via the argument above, significant gender differences still exist in the returns to human capital variables (see Table 4 below) and these differences by convention, should also be included in the unexplained gap.
} 
flexibility and flexibility intensity aspects of different household and market activities $\left(f_{j}\right.$ and $\left.\sigma_{j}\right)$, see Model 2 in Table 4.

Table 3. Model 1: Human capital variables and observed amount of housework on working weekdays.

\begin{tabular}{|c|c|c|c|c|c|c|}
\hline & \multicolumn{2}{|c|}{$10^{\text {th }}$ quantile } & \multicolumn{2}{|c|}{$50^{\text {th }}$ quantile } & \multicolumn{2}{|c|}{$90^{\text {th }}$ quantile } \\
\hline & Women & Men & Women & Men & Women & Men \\
\hline Educational level 2 & $\begin{array}{l}0.039^{*} \\
(0.016)\end{array}$ & $\begin{array}{l}0.126^{*} \\
(0.017)\end{array}$ & $\begin{array}{l}0.032^{*} \\
(0.009)\end{array}$ & $\begin{array}{l}0.051^{*} \\
(0.010)\end{array}$ & $\begin{array}{c}0.006 \\
(0.019)\end{array}$ & $\begin{array}{c}0.018 \\
(0.026)\end{array}$ \\
\hline Educational level 3 & $\begin{array}{l}0.160^{*} \\
(0.024)\end{array}$ & $\begin{array}{l}0.121^{*} \\
(0.022)\end{array}$ & $\begin{array}{l}0.146^{*} \\
(0.018)\end{array}$ & $\begin{array}{l}0.109^{*} \\
(0.021)\end{array}$ & $\begin{array}{l}0.068^{*} \\
(0.034)\end{array}$ & $\begin{array}{c}0.014 \\
(0.047)\end{array}$ \\
\hline Educational level 4 & $\begin{array}{l}0.208^{*} \\
(0.017)\end{array}$ & $\begin{array}{l}0.221^{*} \\
(0.025)\end{array}$ & $\begin{array}{l}0.146^{*} \\
(0.010)\end{array}$ & $\begin{array}{l}0.168^{*} \\
(0.020)\end{array}$ & $\begin{array}{l}0.098^{*} \\
(0.032)\end{array}$ & $\begin{array}{l}0.193 * \\
(0.062)\end{array}$ \\
\hline Educational level 5 & $\begin{array}{l}0.473^{*} \\
(0.022)\end{array}$ & $\begin{array}{c}0.473 * \\
(0.022)\end{array}$ & $\begin{array}{c}0.408 * \\
(0.032)\end{array}$ & $\begin{array}{c}0.463 * \\
(0.025)\end{array}$ & $\begin{array}{l}0.340 * \\
(0.034)\end{array}$ & $\begin{array}{l}0.451^{*} \\
(0.047)\end{array}$ \\
\hline Experience, years & $\begin{array}{l}0.042 * \\
(0.005)\end{array}$ & $\begin{array}{l}0.065^{*} \\
(0.004)\end{array}$ & $\begin{array}{l}0.012^{*} \\
(0.003)\end{array}$ & $\begin{array}{l}0.040^{*} \\
(0.004)\end{array}$ & $\begin{array}{l}-0.009 \\
(0.007)\end{array}$ & $\begin{array}{l}0.027^{*} \\
(0.007)\end{array}$ \\
\hline Experience squared/100 & $\begin{array}{c}-0.096^{*} \\
(0.018)\end{array}$ & $\begin{array}{l}-0.166^{*} \\
(0.013)\end{array}$ & $\begin{array}{c}-0.010 \\
(0.009)\end{array}$ & $\begin{array}{l}-0.104 * \\
(0.012)\end{array}$ & $\begin{array}{l}0.065^{*} \\
(0.029)\end{array}$ & $\begin{array}{c}-0.072 * \\
(0.021)\end{array}$ \\
\hline Market work, daily hours & $\begin{array}{c}0.001 \\
(0.002)\end{array}$ & $\begin{array}{l}0.006^{*} \\
(0.002)\end{array}$ & $\begin{array}{c}-0.001 \\
(0.001)\end{array}$ & $\begin{array}{l}0.009^{*} \\
(0.002)\end{array}$ & $\begin{array}{c}-0.001 \\
(0.002)\end{array}$ & $\begin{array}{c}0.006 \\
(0.003)\end{array}$ \\
\hline Housework, daily hours & $\begin{array}{c}-0.003 \\
(0.004)\end{array}$ & $\begin{array}{l}0.011^{*} \\
(0.004)\end{array}$ & $\begin{array}{c}-0.006^{*} \\
(0.002)\end{array}$ & $\begin{array}{c}0.000 \\
(0.002)\end{array}$ & $\begin{array}{l}0.010^{*} \\
(0.004)\end{array}$ & $\begin{array}{c}-0.014^{*} \\
(0.006)\end{array}$ \\
\hline $\begin{array}{l}\text { Constant term, year } \\
\text { dummies, woman indicator and } \\
\text { region }\end{array}$ & \multicolumn{2}{|c|}{ yes } & \multicolumn{2}{|c|}{ yes } & \multicolumn{2}{|c|}{ yes } \\
\hline Pseudo R square & \multicolumn{2}{|c|}{235} & \multicolumn{2}{|c|}{196} & \multicolumn{2}{|c|}{187} \\
\hline Number of observations & \multicolumn{6}{|c|}{7,718} \\
\hline
\end{tabular}

* significant at the $5 \%$ level.

In the basic model in Table 3 above, the total number of hours spent on housework activities is investigated. This model is basically in line with Hersch (1991a,b), except that we use a quantile regression approach. Table 3 shows that the amount of housework has a negative effect on the hourly wages of women and a positive effect on the hourly wages of men, except at the $90^{\text {th }}$ quantile of the conditional wage distribution where this is reversed. However, the effect of housework on wages is only significant for women at the $50^{\text {th }}$ and $90^{\text {th }}$ quantiles and men at the $10^{\text {th }}$ and $90^{\text {th }}$ quantiles. For women at the $50^{\text {th }}$ quantile, the results indicate that one more hour of daily housework reduces the hourly wage rate significantly by about $6 / 10$ ths of a percent, and for men at the $90^{\text {th }}$ quantile by about $1.4 \%$. Therefore, the group that appears to be most strongly 
penalized are men at the high end of the conditional wage distribution. Surprisingly, for women at the upper end of the conditional wage distribution the effect is significantly positive. Compared to the US studies by Bielby and Bielby (1988), Hersch (1991a,b) and Hersch and Stratton (1997) and Stratton(2001), which do not find negative effects of housework for men but only for women, our results for Denmark are more mixed. ${ }^{12}$

Looking at the other variables of the wage function, it is found, with a few exceptions, that women receive a lower remuneration of their human capital, education and experience and market work hours, at all points of the conditional wage distribution. The wage profile across experience levels is steeper at the lower end of the conditional wage distribution, while at the upper end it is relatively flat. For women in the $90^{\text {th }}$ quantile of the conditional distribution, the coefficient of the experience variable is insignificant.

In the next step, we extend the basic model with variables which may capture flexibility intensity aspects. The variables selected are two indicators for 1 and 2 or more children aged less than 10 years, indicators for being married or cohabiting, occupational categories and employment in the public sector. The occupational indicators are expected among other things to reflect that the level of flexibility demanded from the job and thus the wage rate, vary according to occupational position in the labour market. The public sector variable is expected to capture the fact that public-sector employees have more flexible working conditions (more care days for sick children, flexible working time schedules, more rights concerning parental leave etc.), i.e. the public sector is typically less demanding with respect to the flexibility of the workers. The interpretation of these additional variables should be handled with care, however, since these variables may be considered endogenous to the model. However, for the same reason as for the housework variables, we have not instrumented these variables.

Table 4 below shows that housework coefficients become (numerically) slightly smaller and lose significance when family and job characteristic variables are included in the model, except at the

\footnotetext{
12 To be able to compare our findings more closely with those of the U.S. studies mentioned above that employ simple or augmented OLS regressions, we also run the pooled OLS regression of the model in Table 3 . The coefficient of housework in the pooled model is negative and insignificant for women (-.0002), and positive and insignificant for men (.003), thus in the pooled model, the signs match those found in the previous U.S. studies.
} 
lowest quantile. ${ }^{13}$ Men at the $10^{\text {th }}$ quantile still experience a $1.3 \%$ increase in wages for every additional hour of housework. Further, in contrast to Table 3, women at the highest quantile no longer face a significant positive effect of housework on wages. The coefficients of the classic human capital variables are not altered much by the inclusion of more variables in the wage function. The additional variables reflecting family background are not significant for women. Married women or women with at least one child aged less than 10 years do not earn less than single women or women without young children, whereas men get a 'marriage premium' in the sense that they earn significantly higher wages than other men. ${ }^{14}$ Exactly the same patterns are found for Sweden, see Albrecht et al. (2003). Men as well as women who are employed in the public sector are strongly 'punished', especially at the high end of the conditional wage distribution. The coefficient of the public-sector variable is $-19 \%$ for women and $-24 \%$ for men at the $90^{\text {th }}$ quantile. Since more than $50 \%$ of Danish women (about $20 \%$ of Danish men) are employed in the public sector, the public-sector indicator variable to a large extent 'explains' the gender wage gap. However, the public sector variable may to a large extent capture that individuals, who prefer a 'family-friendly' job to a demanding job with a high wage, choose to work in the public sector. ${ }^{15}$ In the same way, the coefficients to the occupational variables which indicate large wage differentials between occupational categories, may reflect the endogeneity of occupational status.

Before turning to the models incorporating timing and flexibility, one further experiment which is to split housework activities into more detailed groups and analyse whether there are significant differences in the wage effects of activities which are assumed to be more or less

\footnotetext{
${ }^{13}$ In the corresponding pooled OLS regression of this model, the coefficient to housework is $0.0005(0.002)$ for women and $0.006(0.003) *$ for men.

14 The absence of a 'family gap' in women's wages in Denmark has been documented previously by Datta Gupta and Smith (2002).

${ }^{15}$ In the study by Nielsen et al. (2003), the wages of Danish men and women are analysed in a switching regression approach where choice of sector is considered endogenous to the wage determination. When sector is endogenized, the effects of young children and periods out the labour market turn significantly negative.
} 
Table 4. Model 2: Human capital variables, household, occupational and sector variables, and amount of housework on working weekdays.

\begin{tabular}{|c|c|c|c|c|c|c|}
\hline & \multicolumn{2}{|c|}{$10^{\text {th }}$ quantile } & \multicolumn{2}{|c|}{$50^{\text {th }}$ quantile } & \multicolumn{2}{|c|}{$90^{\text {th }}$ quantile } \\
\hline & Women & Men & Women & Men & Women & Men \\
\hline Educational level 2 & $\begin{array}{l}0.045^{*} \\
(0.019)\end{array}$ & $\begin{array}{l}0.118^{*} \\
(0.019)\end{array}$ & $\begin{array}{c}0.022 \\
(0.011)\end{array}$ & $\begin{array}{l}0.029^{*} \\
(0.015)\end{array}$ & $\begin{array}{c}-0.011 \\
(0.021)\end{array}$ & $\begin{array}{l}-0.010 \\
(0.021)\end{array}$ \\
\hline Educational level 3 & $\begin{array}{l}0.150^{*} \\
(0.031)\end{array}$ & $\begin{array}{l}0.156^{*} \\
(0.029)\end{array}$ & $\begin{array}{l}0.121^{*} \\
(0.016)\end{array}$ & $\begin{array}{l}0.119^{*} \\
(0.024)\end{array}$ & $\begin{array}{c}0.013 \\
(0.045)\end{array}$ & $\begin{array}{l}0.079^{*} \\
(0.030)\end{array}$ \\
\hline Educational level 4 & $\begin{array}{l}0.212^{*} \\
(0.022)\end{array}$ & $\begin{array}{l}0.188^{*} \\
(0.033)\end{array}$ & $\begin{array}{l}0.100^{*} \\
(0.018)\end{array}$ & $\begin{array}{l}0.100^{*} \\
(0.018)\end{array}$ & $\begin{array}{c}0.057 \\
(0.048)\end{array}$ & $\begin{array}{c}0.035 \\
(0.053)\end{array}$ \\
\hline Educational level 5 & $\begin{array}{l}0.410^{*} \\
(0.034)\end{array}$ & $\begin{array}{l}0.464^{*} \\
(0.041)\end{array}$ & $\begin{array}{l}0.217^{*} \\
(0.042)\end{array}$ & $\begin{array}{l}0.272^{*} \\
(0.025)\end{array}$ & $\begin{array}{l}0.175^{*} \\
(0.073)\end{array}$ & $\begin{array}{l}0.265^{*} \\
(0.055)\end{array}$ \\
\hline Experience, years & $\begin{array}{l}0.040^{*} \\
(0.005)\end{array}$ & $\begin{array}{l}0.051^{*} \\
(0.005)\end{array}$ & $\begin{array}{l}0.013^{*} \\
(0.003)\end{array}$ & $\begin{array}{l}0.030^{*} \\
(0.003)\end{array}$ & $\begin{array}{c}-0.007 \\
(0.006)\end{array}$ & $\begin{array}{l}0.020^{*} \\
(0.006)\end{array}$ \\
\hline Experience squared/100 & $\begin{array}{l}-0.093 * \\
(0.018)\end{array}$ & $\begin{array}{l}-0.129 * \\
(0.016)\end{array}$ & $\begin{array}{l}-0.016 \\
(0.012)\end{array}$ & $\begin{array}{c}-0.072 * \\
(0.010)\end{array}$ & $\begin{array}{l}0.050^{*} \\
(0.024)\end{array}$ & $\begin{array}{l}-0.052 * \\
(0.020)\end{array}$ \\
\hline Market work, daily hours & $\begin{array}{c}-0.002 \\
(0.002)\end{array}$ & $\begin{array}{l}0.006^{*} \\
(0.002)\end{array}$ & $\begin{array}{c}-0.002 \\
(0.001)\end{array}$ & $\begin{array}{l}0.003^{*} \\
(0.001)\end{array}$ & $\begin{array}{l}-0.007^{*} \\
(0.003)\end{array}$ & $\begin{array}{c}0.003 \\
(0.002)\end{array}$ \\
\hline Married or cohabiting & $\begin{array}{c}0.012 \\
(0.017)\end{array}$ & $\begin{array}{l}0.096^{*} \\
(0.018)\end{array}$ & $\begin{array}{c}-0.000 \\
(0.009)\end{array}$ & $\begin{array}{l}0.019^{*} \\
(0.012)\end{array}$ & $\begin{array}{c}0.036 \\
(0.019)\end{array}$ & $\begin{array}{l}0.043^{*} \\
(0.018)\end{array}$ \\
\hline 1 child aged less than 10 years & $\begin{array}{c}0.010 \\
(0.018)\end{array}$ & $\begin{array}{c}-0.023 \\
(0.017)\end{array}$ & $\begin{array}{c}-0.015 \\
(0.010)\end{array}$ & $\begin{array}{c}0.024 \\
(0.013)\end{array}$ & $\begin{array}{l}-0.015 \\
(0.023)\end{array}$ & $\begin{array}{c}0.042 \\
(0.022)\end{array}$ \\
\hline 2 or more children aged less than 10 years & $\begin{array}{c}0.017 \\
(0.019)\end{array}$ & $\begin{array}{c}0.012 \\
(0.020)\end{array}$ & $\begin{array}{c}-0.013 \\
(0.013)\end{array}$ & $\begin{array}{l}0.023^{*} \\
(0.015)\end{array}$ & $\begin{array}{c}-0.023 \\
(0.032)\end{array}$ & $\begin{array}{c}0.016 \\
(0.027)\end{array}$ \\
\hline Public sector & $\begin{array}{c}-0.007 \\
(0.014)\end{array}$ & $\begin{array}{c}-0.081 * \\
(0.014)\end{array}$ & $\begin{array}{c}-0.101^{*} \\
(0.009)\end{array}$ & $\begin{array}{c}-0.160 * \\
(0.010)\end{array}$ & $\begin{array}{c}-0.187 * \\
(0.022)\end{array}$ & $\begin{array}{l}-0.242 * \\
(0.028)\end{array}$ \\
\hline Salaried, high level & $\begin{array}{l}0.089^{*} \\
(0.022)\end{array}$ & $\begin{array}{l}0.144^{*} \\
(0.026)\end{array}$ & $\begin{array}{l}0.196^{*} \\
(0.028)\end{array}$ & $\begin{array}{l}0.323 * \\
(0.023)\end{array}$ & $\begin{array}{l}0.228^{*} \\
(0.067)\end{array}$ & $\begin{array}{l}0.380^{*} \\
(0.042)\end{array}$ \\
\hline Salaried, medium level & $\begin{array}{c}-0.008 \\
(0.017)\end{array}$ & $\begin{array}{l}0.087^{*} \\
(0.021)\end{array}$ & $\begin{array}{c}0.087 * \\
(0.015)\end{array}$ & $\begin{array}{l}0.133^{*} \\
(0.016)\end{array}$ & $\begin{array}{c}0.098 * \\
(0.048)\end{array}$ & $\begin{array}{l}0.084 * \\
(0.025)\end{array}$ \\
\hline Skilled workers & $\begin{array}{c}-0.084 \\
(0.092)\end{array}$ & $\begin{array}{l}-0.010 \\
(0.023)\end{array}$ & $\begin{array}{c}0.042 \\
(0.041)\end{array}$ & $\begin{array}{l}0.097 * \\
(0.017)\end{array}$ & $\begin{array}{c}-0.045 \\
(0.087)\end{array}$ & $\begin{array}{c}0.056 \\
(0.029)\end{array}$ \\
\hline Unskilled workers, medium level & $\begin{array}{c}0.000 \\
(0.022)\end{array}$ & $\begin{array}{l}0.067^{*} \\
(0.019)\end{array}$ & $\begin{array}{c}0.000 \\
(0.013)\end{array}$ & $\begin{array}{l}0.044 * \\
(0.021)\end{array}$ & $\begin{array}{c}-0.044 \\
(0.023)\end{array}$ & $\begin{array}{c}0.014 \\
(0.032)\end{array}$ \\
\hline Unskilled workers, low level & $\begin{array}{c}-0.106^{*} \\
(0.034)\end{array}$ & $\begin{array}{l}-0.124^{*} \\
(0.032)\end{array}$ & $\begin{array}{c}-0.034 \\
(0.025)\end{array}$ & $\begin{array}{c}0.003 \\
(0.023)\end{array}$ & $\begin{array}{c}0.018 \\
(0.057)\end{array}$ & $\begin{array}{c}0.037 \\
(0.057)\end{array}$ \\
\hline Housework, daily hours & $\begin{array}{l}-0.005 \\
(0.005)\end{array}$ & $\begin{array}{l}0.013^{*} \\
(0.004)\end{array}$ & $\begin{array}{l}-0.003 \\
(0.003)\end{array}$ & $\begin{array}{c}0.003 \\
(0.004)\end{array}$ & $\begin{array}{c}0.009 \\
(0.006)\end{array}$ & $\begin{array}{l}-0.007 \\
(0.006)\end{array}$ \\
\hline $\begin{array}{l}\text { Constant term, year dummies, woman indicator } \\
\text { and region }\end{array}$ & \multicolumn{2}{|c|}{ yes } & \multicolumn{2}{|c|}{ yes } & \multicolumn{2}{|c|}{ yes } \\
\hline Pseudo R square & \multicolumn{2}{|c|}{259} & \multicolumn{2}{|c|}{249} & \multicolumn{2}{|c|}{264} \\
\hline Number of observations & \multicolumn{6}{|c|}{7,718} \\
\hline
\end{tabular}

*Significant at the 5\% level. 
flexibility intensive. ${ }^{16}$

\section{B. Timing and Flexibility of Housework}

In Tables 5-6, we try to measure flexibility of housework more directly. We also experiment with measuring flexibility and timing aspects in alternative ways. One indicator of having low flexibility on the job and giving higher priority to family tasks may be that the individual does housework both before and just after being at the job. Thus, in Model 3, we add an indicator variable additional to the amount of housework, which assumes the value of 1 for persons who based on their time diaries are observed to fulfill this criterion.

The first two rows of Table 5 below show the results of this estimation. This aspect of timing and flexibility clearly has an effect on observed wages, and the effect is much more negative and significant for women than for men, except for men at the upper end of the conditional wage distribution who also face a significant negative effect. Further, the effect on wages of housework before and after work is considerably larger than the effect of the level of housework. The wages of women, who do housework just before and after their job, are on average 3.2\% $(3.3 \%)$ lower than for other women at the $10^{\text {th }}\left(50^{\text {th }}\right)$ quantile of the conditional wage distribution. At the $90^{\text {th }}$ quantile, the effect is as large as $-4.6 \%$ for women and $-3.7 \%$ for men.

\footnotetext{
${ }^{16}$ Housework categories are 'Food preparation, dish washing etc.', 'Cleaning etc.', 'Child care and child transportation', 'Do-it-yourself work' and 'Shopping, services etc.' (see Table 1). Our a priori expectation is that food preparation, cleaning and child care are less flexible activities than do-it-yourself work, and therefore these activities may have more negative effects on the wage growth, see Noonan (2001), for similar evidence from US data. The results show that our a priori expectations are to some extent fulfilled. However, women at the high end of the conditional wage distribution are not penalized more from doing routine tasks like cleaning and food preparation activities. On the contrary, cleaning activities have a positive and significant effect on women's wages at the $90^{\text {th }}$ quantile! One explanation for this may be that women with demanding jobs can move the more inflexible cleaning tasks to the weekend or purchase cleaning services in the market despite the high prices of these services, and thereby only undertake time-flexible cleaning activities which are not damaging to wages on weekdays.
} 
Table 5. Selected results from models reflecting timing and flexibility aspects. Extended model, Model $2^{1)}$.

\begin{tabular}{|c|c|c|c|c|c|c|}
\hline & \multicolumn{2}{|c|}{$10^{\text {th }}$ quantile } & \multicolumn{2}{|c|}{$50^{\text {th }}$ quantile } & \multicolumn{2}{|c|}{$90^{\text {th }}$ quantile } \\
\hline & Women & Men & Women & Men & Women & Men \\
\hline \multicolumn{7}{|l|}{$\begin{array}{l}\text { Model 3: Both morning and afternoon } \\
\text { housework (No. of observations } 7,718 \text { ) }\end{array}$} \\
\hline Hours of housework & $\begin{array}{l}-0.002 \\
(0.004)\end{array}$ & $\begin{array}{l}0.013^{*} \\
(0.004)\end{array}$ & $\begin{array}{l}-0.002 \\
(0.002)\end{array}$ & $\begin{array}{c}0.004 \\
(0.004)\end{array}$ & $\begin{array}{l}0.014^{*} \\
(0.005)\end{array}$ & $\begin{array}{l}-0.006 \\
(0.005)\end{array}$ \\
\hline Indicator for morning and afternoon housework & $\begin{array}{l}-0.032 * \\
(0.014)\end{array}$ & $\begin{array}{l}-0.002 \\
(0.012)\end{array}$ & $\begin{array}{l}-0.033^{*} \\
(0.008)\end{array}$ & $\begin{array}{l}-0.020 \\
(0.011)\end{array}$ & $\begin{array}{l}-0.046^{*} \\
(0.018)\end{array}$ & $\begin{array}{l}-0.037^{*} \\
(0.021)\end{array}$ \\
\hline \multicolumn{7}{|l|}{$\begin{array}{l}\text { Model 4: Contiguity of housework spells } \\
\text { (No. of observations } 7,718 \text { ) }\end{array}$} \\
\hline Hours of housework & $\begin{array}{l}-0.006 \\
(0.005)\end{array}$ & $\begin{array}{c}0.002 \\
(0.007)\end{array}$ & $\begin{array}{l}0.0005 \\
(0.003)\end{array}$ & $\begin{array}{l}-0.001 \\
(0.006)\end{array}$ & $\begin{array}{l}0.019 * \\
(0.007)\end{array}$ & $\begin{array}{l}-0.010 \\
(0.006)\end{array}$ \\
\hline Average spell length of housework & $\begin{array}{c}0.028 \\
(0.051)\end{array}$ & $\begin{array}{l}0.071^{*} \\
(0.029)\end{array}$ & $\begin{array}{l}-0.036 \\
(0.023)\end{array}$ & $\begin{array}{c}0.018 \\
(0.021)\end{array}$ & $\begin{array}{l}-0.089 * \\
(0.041)\end{array}$ & $\begin{array}{c}0.018 \\
(0.029)\end{array}$ \\
\hline
\end{tabular}

Apart from the timing aspect, another way to capture the notion of flexibility of housework is to measure the contiguity of housework spells, i.e. some tasks need long periods of time in order to be completed satisfactorily. Thus, we try to come up with an objective measure of whether or not housework requires contiguous time blocks by taking an average over the individual's spells of housework over the course of the day. This variable, the average spell length of housework is tried in place of the timing indicators, but along with the quantity of housework, in Model 4 which appears in the lower panel of Table 5 above. We expect that individuals who do tasks that appear to take more contiguous time in their time diaries (higher average housework spell) will be penalized more than people who have on average shorter spells of housework chores. The results from this model indicate that particularly women at the high end of the conditional wage distribution are penalized from having a higher average housework spell, and this penalty is large, around 9\%! Other groups however appear not to be penalized for the contiguity of their housework spells.

In Table 6 below we return to the first definition of flexibility and test the sensitivity of our findings to alternative specifications and alternative sample definitions. First, the notion of time flexibility introduced in Table 5 above assumed that individuals who did housework before and 
after the job were constrained by the dictates of their housework to cut down their work hours and therefore that the effects on productivity and hence wages of such behaviour were necessarily negative. However, the causation could go the other way in that some employees can bargain flexible work schedules with their employers, affording them the flexibility to time their work and housework according to the changing needs of the family or employer. In fact, this type of bargained time flexibility could increase productivity and wages because it may increase job satisfaction etc. for the employee without conflicting with the demands of the employer. In order to try to distinguish between these hypotheses, we use additional information from the time use survey in which individuals are asked whether or not their jobs require fixed hours work schedules or flexible hours work schedules that are a part of a bargain made with the employer. ${ }^{17}$

Around $6 \%$ of men and 3\% of women report having flexible hours work schedules that are determined through bargaining with the employer. Model $3 \mathrm{a}$ in Table 6 below shows that when the indicator for doing housework just before or just after the job is interacted with having fixed or flexible work schedules, exactly as predicted, negative effects arise for those (significant mostly for women) on fixed work schedules, while positive effects arise (significant mostly for men) for those who have flexible work schedules. Thus, it may be important to distinguish whether the timing of housework just before or after work is flexibly chosen by the individual or enforced upon the individual as a result of time-inflexible household duties or family responsibilities.

Another way to analyse whether the flexibility of housework matters is to restrict the samples to groups, that are more homogenous with respect to flexibility. One hypothesis is that married people face many more routine tasks that make them more inflexible than single people because they have to coordinate the timing of housework tasks like food preparing, shopping etc. with the spouse. Especially for women, we expect this effect to exist. For men, an opposite effect from being married can arise if the wife takes the main responsibility for activities at home. This may

\footnotetext{
${ }^{17}$ The actual question is worded as following: Do you have fixed work hours or variable work hours? The choices given are fixed daytime work hours, fixed evening/night work hours, variable daytime work hours and variable evening/night work hours. For those that answer some type of variable hours, a further question probes the actual nature of varying work hours, i.e. shift work ( 2 shifts), shift work ( 3 or more shifts with weekend breaks), shift work ( 3 or more shifts without weekend breaks), varying according to employer's plan, varying according to bargain with employer, including flextime. Only the last group is considered to be on flexible work schedules.
} 
Table 6. Specification tests involving flexibility of housework model. Extended model, Model $2^{1)}$.

\begin{tabular}{|c|c|c|c|c|c|c|}
\hline & \multicolumn{2}{|c|}{$10^{\text {th }}$ quantile } & \multicolumn{2}{|c|}{$50^{\text {th }}$ quantile } & \multicolumn{2}{|c|}{$90^{\text {th }}$ quantile } \\
\hline & Women & Men & Women & Men & Women & Men \\
\hline \multicolumn{7}{|l|}{$\begin{array}{l}\text { Model 3a: Including interactions with work } \\
\text { schedule flexibility } \\
\text { (No. of observations 7,718) }\end{array}$} \\
\hline Hours of housework & $\begin{array}{l}-0.001 \\
(0.004)\end{array}$ & $\begin{array}{l}0.014^{*} \\
(0.003)\end{array}$ & $\begin{array}{l}-0.002 \\
(0.002)\end{array}$ & $\begin{array}{c}0.003 \\
(0.003)\end{array}$ & $\begin{array}{l}0.011^{*} \\
(0.005)\end{array}$ & $\begin{array}{l}-0.006 \\
(0.006)\end{array}$ \\
\hline $\begin{array}{l}\text { Indicator for morning and afternoon } \\
\text { housework*flexible work schedules }\end{array}$ & $\begin{array}{c}0.029 \\
(0.036)\end{array}$ & $\begin{array}{l}0.108^{*} \\
(0.031)\end{array}$ & $\begin{array}{c}0.076 \\
(0.065)\end{array}$ & $\begin{array}{l}0.054^{*} \\
(0.025)\end{array}$ & $\begin{array}{l}0.150^{*} \\
(0.040)\end{array}$ & $\begin{array}{l}-0.027 \\
(0.197)\end{array}$ \\
\hline $\begin{array}{l}\text { Indicator for morning and afternoon } \\
\text { housework*fixed work schedules }\end{array}$ & $\begin{array}{r}-0.035^{*} \\
(0.014)\end{array}$ & $\begin{array}{l}-0.004 \\
(0.015)\end{array}$ & $\begin{array}{l}-0.034^{*} \\
(0.008)\end{array}$ & $\begin{array}{l}-0.031^{*} \\
(0.012)\end{array}$ & $\begin{array}{l}-0.053^{*} \\
(0.019)\end{array}$ & $\begin{array}{l}-0.038 \\
(0.020)\end{array}$ \\
\hline \multicolumn{7}{|l|}{$\begin{array}{l}\text { Model } 3 b \text { : Married and cohabiting individuals } \\
\text { only } \\
\text { (No. of observations } 5,715 \text { ) }\end{array}$} \\
\hline Hours of housework & $\begin{array}{l}-0.007 \\
(0.005)\end{array}$ & $\begin{array}{l}0.009^{*} \\
(0.004)\end{array}$ & $\begin{array}{l}-0.004 \\
(0.003)\end{array}$ & $\begin{array}{l}-0.002 \\
(0.004)\end{array}$ & $\begin{array}{c}0.009 \\
(0.005)\end{array}$ & $\begin{array}{l}-0.006 \\
(0.005)\end{array}$ \\
\hline Indicator for morning and afternoon housework & $\begin{array}{l}-0.043 * \\
(0.017)\end{array}$ & $\begin{array}{l}-0.015 \\
(0.016)\end{array}$ & $\begin{array}{l}-0.043^{*} \\
(0.010)\end{array}$ & $\begin{array}{l}-0.012 \\
(0.012)\end{array}$ & $\begin{array}{l}-0.063^{*} \\
(0.019)\end{array}$ & $\begin{array}{l}-0.048^{*} \\
(0.023)\end{array}$ \\
\hline \multicolumn{7}{|l|}{$\begin{array}{l}\text { Model 3c: Housework including indirect child } \\
\text { care } \\
\text { (No. of observations } 7,718 \text { ) }\end{array}$} \\
\hline Hours of housework & $\begin{array}{r}-0.004 * \\
(0.002)\end{array}$ & $\begin{array}{l}0.007^{*} \\
(0.002)\end{array}$ & $\begin{array}{l}-0.001 \\
(0.001)\end{array}$ & $\begin{array}{l}0.004^{*} \\
(0.002)\end{array}$ & $\begin{array}{c}0.004 \\
(0.003)\end{array}$ & $\begin{array}{c}0.002 \\
(0.003)\end{array}$ \\
\hline Indicator for morning and afternoon housework & $\begin{array}{c}-0.031^{*} \\
(0.014)\end{array}$ & $\begin{array}{c}0.007 \\
(0.013)\end{array}$ & $\begin{array}{l}-0.032 * \\
(0.008)\end{array}$ & $\begin{array}{l}-0.024^{*} \\
(0.011)\end{array}$ & $\begin{array}{c}-0.038^{*} \\
(0.019)\end{array}$ & $\begin{array}{l}-0.035 \\
(0.021)\end{array}$ \\
\hline
\end{tabular}

1) Model 2, see Table 4.

* significant at a $5 \%$ level.

increase the amount of flexibility that married men devote to their jobs. In Model 3b, we therefore restrict the estimation of Model 3 to include only married or cohabiting persons. One weakness of our sample is that we only have time use information for the year 1987 which is used for all subsequent 4 years. The allocation of time may, of course, be affected during the period if the person changes civil state (or other major changes). However, when restricting our sample to individuals observed as non-singles, we may partly take account for the lack of annual time use information, and if civil state affects the flexibility of work, we should expect to see stronger results with respect to the wage effects of housework, especially at the upper end of the female wage distribution. For men, we may find the opposite if their wives are mainly responsible for time-inflexible housework. According to Table 6 above, this is in fact the case. 
Hours of housework become more negative for all groups and in fact, is no longer significantly positive for women at the $90^{\text {th }}$ quantile. Regarding time flexibility, effects become stronger for women and slightly weaker (though still negative) for men except men at the $90^{\text {th }}$ quantile. For the $90^{\text {th }}$ quantile, the coefficient of morning and afternoon housework becomes really large for married or cohabiting individuals, $-6.3 \%$ for women and $-4.8 \%$ for men. The indicator for doing housework immediately before and after the job also becomes more negative for married women at the other points of the conditional wage distribution though less negative for married men. These findings would indicate that, given the prevalence of assortative mating, at the high end of the distribution there is more sharing of housework between partners so that both partners are affected by the coordination problem, while at other points, married women are penalized more and married men less perhaps because in this case it is women who are mainly responsible for the 'balancing act'.

As a final test of robustness of results to alternative definitions, in Model 3c in Table 6 above, we experiment with a different measure of housework, one which includes both direct and indirect child-care activities i.e. child care that is done simultaneously with other housework or leisure activities. The mean values for indirect child care can be seen in Appendix C. For example, while men (women) in 1987 spent $0.16(0.36)$ hours on direct child care and child transportation, the numbers for indirect child care are much higher, 2.07 (3.24) hours. One reason for taking this into is that child care activities are typically the most widespread type of secondary activity that individuals engage in and as such, captures the wage effects of 'multitasking' within the household. If such dual tasking increases stress or fatigue, we would expect more negative effects of the amount and timing of housework than when these activities are not accounted for. Findings show that the coefficients to the amount and timing of housework are not appreciably altered in Model 3c compared to Model 3 and we conclude that recoding housework to include secondary activities that involve children as child care does not change the results and that the wage effects of flexibility are not appreciably altered if tasks are done simultaneously with children. 


\section{Conclusion}

In this paper, we analyse whether the amount and timing or flexibility of housework have negative effects on the wages of men and women. We find like in the U.S. studies, that housework has negative effects on the wages of women and positive effects on the wages of men, except at the high end of the conditional wage distribution. At the $90^{\text {th }}$ quantile, housework has a positive effect on the wages of women and a negative effect on the wages of men. In fact, high-wage men receive the largest wage penalty of doing housework, namely, a wage loss of $1.4 \%$ for each additional hour of housework done during the weekday.

The coefficient to housework becomes numerically smaller and less significant when family and job characteristics are added to the model. These characteristics can be thought of as indirectly measuring flexibility intensity. Of these, public sector employment is particularly important to wages, especially at the high end of the conditional wage distribution. At the $90^{\text {th }}$ quantile, public-sector employed women earn 19\% less than private-sector employed women, while the same figure for men is $24 \%$. Since unions in the public sector prioritize non-wage benefits such as long maternity leave with full wage compensation, care days, flexible working schedules, and during the latest years even reduced hours instead of wage increases, the large negative effect of public-sector employment may indirectly reflect the importance of flexibility and home responsibilities.

When looking directly at timing and flexibility aspects, we do find evidence that the timing and flexibility aspects matter for wages and in fact considerably more than the quantity (amount) of housework. Women (and to a smaller extent men) who do housework activities immediately before or after their job have significantly lower wage rates, especially at the upper end of the conditional wage distribution, where the wage penalty for women is $4.6 \%$ and $3.7 \%$ for men. Further, high-wage women whose average housework spell requires contiguous blocks of time face a wage penalty of $9 \%$. It is important however to distinguish whether the timing of housework just before or after work is flexibly chosen by the individual or enforced upon the individual as a result of time-inflexible household duties or family responsibilities that cannot be moved and only the latter appear to be damaging to productivity and wages.

Wage effects of flexibility are numerically larger for married or cohabiting women but slightly 
weaker for men in such households, except at the $90^{\text {th }}$ quantile. At the $90^{\text {th }}$ quantile, the coefficient of morning and afternoon housework becomes really large for both married men and married women, $-6.3 \%$ for women and $-4.8 \%$ for men. This asymmetry may indicate that, assuming assortative mating behaviour, there is more sharing of housework tasks at the high end of the distribution so that both partners are negatively affected by the coordination problem but that lower down the distribution women take more of the responsibility for coordinating home activities.

Finally, we test the robustness of our housework measure to alternative definition of child care. The expanded definition of child care includes both direct child care as well as child care that is recorded as a secondary activity done simultaneously with other housework or leisure activities. The results show that re-measuring housework to take into account secondary child care activities does not alter the results appreciably and therefore, dual-tasking does not appear damaging to wages.

Our study is the first to try to quantify the effects of timing and flexibility of housework on the wages of men and women in Denmark. The main finding seems to be that women more than men are penalized for inflexibility, and that this is most pronounced at the high end of the conditional wage distribution. Due to the very compressed wage structures in the Scandinavian countries and high tax levels which in turn imply high prices of market services (domestic help, restaurant visits etc.), even high-income families in Scandinavia undertake more housework and do-it-yourself work compared to families for instance in the US. At the same time, early closing of shops and daycare institutions imparts a certain inflexibility to particularly women's daily schedules which our study shows has negative effects on earnings and the career, especially at the higher end of the qualification distribution. This may be one explanation for the increasing unexplained gender wage gap at the upper end of the wage distribution in Denmark. 


\section{References}

Albrecht, J, A. Björklund and S. Vroman. (2003), Is There a Glass-Ceiling in Sweden?. Journal of Labor Economics, Vol. 21, No. 1, pp. 145-177.

Arias, O, K. Hallock and W. Sosa-Escudero (2002), Individual Heterogeneity in the Returns to Schooling:Instrumental Variables Quantile Regression using Twins Data, Economic Applications of Quantile Regressions, Physica Verlag, 7-40.

Becker, G. S. (1985), Human Capital, Effort, and the Sexual Division of Labor. Journal of Labor Economics, vol. 3, no. 1, S33-S58.

Bielby, D. D. and W. T. Bielby (1988), She works hard for the money: Household responsibilities and the allocation of work effort. American Journal of Sociology, 93, 1031-1059.

Bound, J, D.A. Jaeger and R. Baker (1995), Problems with instrumental variables estimation when the correlation between the instruments and the endogenous explanatory variable is weak. Journal of American Statistical Association 90 (430), 443-450.

Buchinsky, M. (1998), Recent Advances in Quantile Regression Models: A practical guideline for empirical research. Journal of Human Resources 33, 88-126.

Chay, K. (1995), Evaluating the impact of the Civil Rights Act of 1964 on the Economic Status of Black Men Using Censored Longitudinal Earnings Data, reprint.

Datta Gupta, N. and N. Smith (2002), Children and Career Interruptions: The Family Gap in Denmark. Economica,Vol. 69, no. 276, 609-629.

Datta Gupta, N., R. Oaxaca, and N. Smith (2003), Swimming Upstream, Floating Downstream: The Different Trends in the US and Danish Gender Wage Differentials in the 1980s and 1990s, IZA Discussion Paper \#756, IZA, Bonn.

Gronau, R. and D. Hamermesh (2001), The Demand for variety: A household production perspective, NBER Working Paper \#8509, NBER, Cambridge, Massachusetts.

Hamermesh, D. (2003), Routine, paper presented at the $2^{\text {nd }}$ IZA/BIRC Conference of the International Research Consortium in the Economics of Time Use, St. Gerlach, the Netherlands.

Hersch, J. (1991a), The Impact of Non Market Work on Market Wages. American Economic Review, Papers and Proceedings, 157-161.

Hersch, J. (1991b), Male-Female Differentials in Hourly Wages: The Role of Human Capital, Working Conditions, and Housework. Industrial and Labor Relations Review 44, no. 4, 746-759.

Hersch, J. and S. Stratton (1997), Housework, Fixed Effects, and Wages of Married Workers. Journal of Human Resources, vol. 32, no. 2, 285-307.

Hersch, J. and S. Stratton (2000), Housework and Wages, Discussion Paper No. 300, Harvard Law School, Cambridge.

Jacobsen, J. P. and P. Kooreman (2003), Timing Constraints and the Allocation of Time: The Effects of Changes in Shopping Hours Regulations in the Netherlands', paper presented at the $2^{\text {nd }}$ IZA/BIRC Conference of the International Research Consortium in the Economics of Time Use, St. Gerlach, the Netherlands.

Koenker, R. and G. Basset (1978), Regression Quantiles. Econometrica, 46, 33-50.

Koenker, R. and K. Hallock (forthcoming), Quantile Regression: An Introduction, Journal of Economic Perspectives "Symposium on Econometric Tools". 
Moulton, B. J. (1990), An Illustration of Pitfalls in Estimating the Groups Effects of Aggregate Variables on observations on Micro Units. Review of Economics and Statistics, 72, 2, 334-338.

Nielsen, H. S., M. Simonsen, and M. Verner (2003), Does the Gap in Family-friendly Policies Drive the Family Gap?, WP 03-01, Department of Economics, University of Aarhus, and WP 02-19, Department of Economics, Aarhus School of Business.

Noonan, M. C. (2001), The Impact of Domestic Work on Men's and Women's Wages. Journal of Marriage and Family 63, 1134-1145.

Phipps, S., P. Burton, and L. Lethbridge (2001), In and out of the labour market: long term consequences of childrelated interruptions to women's paid work. Canadian Journal of Economics, 34, no. 2, 411-429.

Schettkat R. (2003), Differences in US-German Time-Allocation: Why Do Americans Work Longer Hours than Germans? IZA Discussion Paper no. 697, IZA, Bonn.

Stratton, L. (2001), Why does more housework lower women's wages?: Testing hypotheses involving job effort and hours flexibility. Social Science Quarterly, 82, No. 1, 67-76. 


\section{Appendix A}

\section{Theoretical Model - the maximization problem}

We assume the household produces two services $(j=1,2)$, which are determined by two production functions that combine market goods or services bought in the market, $x_{j}$, with efficiency units of time, $I_{j}, j=1,2$ :

$$
Z_{j}=Z_{j}\left(x_{j}, I_{j}\right)
$$

The individual is assumed to maximize her utility function which is a function of the produced goods and services $Z_{1}$ and $Z_{2}$ :

$$
U=U\left(Z_{1}, Z_{2}\right)
$$

The budget constraint is given as

$$
p_{1} x_{1}+p_{2} \mathrm{x}_{2}=w_{m}\left(f_{m}\right) t_{m}+Y
$$

where $Y$ is the non-wage income of the household which in this single person model may include earnings of the spouse, since we do not model interaction between the spouses with respect to effort and time allocation. ${ }^{18}$

Maximization of (A.2) with respect to the choice variables $x_{j}$, $f_{j}$, and $t_{j}$ subject to the budget, time and flexibility constraints and the production functions (1), (2a), (A.1) and (A.3) gives the first order conditions

$$
\begin{aligned}
& \frac{\partial U}{\partial Z_{j}} \frac{\partial Z_{j}}{\partial x_{j}}-\lambda_{x} p_{j}=U_{x_{j}}-\lambda_{x} p_{j}=0 \text { for } j=1,2 \\
& \frac{\partial U}{\partial Z_{j}} \frac{\partial Z_{j}}{\partial I_{j}} \frac{\partial I_{j}}{\partial t_{j}}-\lambda_{t}-\lambda_{f} f_{j}=U_{I_{j}} w_{j}-\lambda_{t}-\lambda_{f} f_{j}=0, \text { for } j=1,2
\end{aligned}
$$

$$
\begin{aligned}
& \lambda_{x} w_{m}-\lambda_{t}-\lambda_{f} f_{m}=0 \\
& \frac{\partial U}{\partial Z_{j}} \frac{\partial Z_{j}}{\partial I_{j}} \frac{\partial I_{j}}{\partial e_{j}}-\lambda_{f} t_{j}=U_{I_{j}} t_{j} \frac{d w_{j}}{d e_{j}}-\lambda_{f} t_{j}=0, \text { for } j=1,2 \\
& \lambda_{x} t_{m} \frac{d w_{m}}{d f_{m}}-\lambda_{f} t_{m}=0
\end{aligned}
$$

where $\lambda_{x}, \lambda_{t}$ and $\lambda_{f}$ are the marginal utilities of income, time and flexibility. The second and third conditions state that the marginal utility of one extra hour spent on non-market activity $j$ or market work must equal the marginal cost of the hour $\left(\lambda_{t}\right)$ plus the flexibility cost related to this $\operatorname{hour}\left(\lambda_{f} f_{j}\right)$. Parallel for the fourth and fifth conditions which relate to one extra unit of flexibility spent on non-market activities and market work (A.4) and the budget constraints define the demand and supply functions for $x_{j}, f_{j}$, and $t_{j}$ as functions of endowment of human capital in different activities, flexibility intensities, prices and non-wage income.

\footnotetext{
18 The present sample does not include information on spouses, and thus we are not able to model time allocation between spouses within the household.
} 


\section{Appendix B}

List of activities recorded in the Danish time use survey 1987:

1. Sleep

2. Personal care

3. Eating

4. Food preparation

5. Dish washing

6. Household upkeep

7. Care for clothes

8. Child care

9. Construction and repair

10. Gardening

11. Employment at home

12. Homework

13. Reading newspapers

14. Reading periodicals and books

15. Hobbies

16. Visit by family (at home)

17. Visit by friends and others (at home)

18. TV and video

19. Radio

20. Music

21. Socializing with family

22. Resting

23. Other at home (telephone etc.)

24. Transporting a child

25. Travel to/from work

26. Travel to/from school or university

27. Other travels

28. Employment

29. School or University

30. Participatory activities

31. Sports

32. Trips

33. Visit family

34. Visit friends and others

35. Shopping

36. Services

37. Restaurant

38. Entertainment and culture

39. Others (outside home) 


\section{Appendix C}

Table C1. Sample means. Selected years. 1987 and 1991.

\begin{tabular}{|c|c|c|c|c|}
\hline & \multicolumn{2}{|l|}{ Men } & \multicolumn{2}{|l|}{ Women } \\
\hline & 1987 & 1991 & 1987 & 1991 \\
\hline Log hourly wage rate & $4.734(0.349)$ & $4.859(0.333)$ & $4.511(0.301)$ & $4.651(0.293)$ \\
\hline $\begin{array}{l}\text { Daily hours of: } \\
\text { Total amount of housework, working weekdays }\end{array}$ & $1.354(1.720)$ & & $2.845(2.129)$ & \\
\hline Total amount of housework, weekend days & $2.194(2.286)$ & & $3.175(2.419)$ & \\
\hline Total amount of housework, new def, weekdays & $2.753(3.227)$ & & $5.368(4.317)$ & \\
\hline Total amount of housework, new def, weekend & $5.411(5.253)$ & & $7.789(6.034)$ & \\
\hline Food preparing $(4,5)$ & $0.481(0.652)$ & & $1.109(0.936)$ & \\
\hline Cleaning $(6,7)$ & $0.122(0.436)$ & & $0.679(1.116)$ & \\
\hline Child care and child transportation $(8,24)$ & $0.162(0.580)$ & & $0.363(0.909)$ & \\
\hline Child care, indirect & $2.066(3.387)$ & & $3.235(4.016)$ & \\
\hline Shopping, services etc $(35,36)$ & $0.319(0.729)$ & & $0.402(0.727)$ & \\
\hline Do-it-yourself work $(9,10)$ & $0.581(1.483)$ & & $0.393(1.081)$ & \\
\hline Paid work, working weekdays & $8.217(3.972)$ & & $6.430(3.635)$ & \\
\hline Paid work, weekend days & $1.414(3.393)$ & & $1.035(2.651)$ & \\
\hline $\begin{array}{l}\text { Indicator for housework both before and after } \\
\text { paid work }\end{array}$ & $0.151(0.358)$ & & $0.334(0.472)$ & \\
\hline Average spell length of housework & $0.411(0.471)$ & & $0.511(0.347)$ & \\
\hline Average spell length of paid work & $1.613(1.668)$ & & $1.283(1.239)$ & \\
\hline Indicator for flexible work schedules & $0.062(0.241)$ & & $0.028(0.165)$ & \\
\hline Education, $9-10$ years & $0.321(0.467)$ & $0.261(0.439)$ & $0.402(0.491)$ & $0.348(0.477)$ \\
\hline Education, $11-12$ years & $0.488(0.500)$ & $0.530(0.499)$ & $0.365(0.482)$ & $0.390(0.488)$ \\
\hline Education, $13-14$ years & $0.042(0.201)$ & $0.050(0.217)$ & $0.046(0.210)$ & $0.050(0.218)$ \\
\hline Education, $15-16$ years & $0.096(0.295)$ & $0.104(0.305)$ & $0.164(0.371)$ & $0.186(0.389)$ \\
\hline Education, $17-18$ years & $0.054(0.226)$ & $0.056(0.229)$ & $0.022(0.147)$ & $0.026(0.158)$ \\
\hline Years of experience & $13.954(7.271)$ & $16.875(7.622)$ & $10.336(5.913)$ & $13.440(6.473)$ \\
\hline Years of experience squared/100 & $2.475(2.031)$ & $3.428(2.572)$ & $1.418(1.431)$ & $2.225(1.924)$ \\
\hline Controls for Copenhagen & $0.306(0.461)$ & $0.306(0.461)$ & $0.366(0.482)$ & $0.375(0.484)$ \\
\hline Public employment & $0.230(0.421)$ & $0.220(0.414)$ & $0.467(0.499)$ & $0.475(0.500)$ \\
\hline One child aged $0-9$ years & $0.120(0.347)$ & $0.151(0.358)$ & $0.197(0.398)$ & $0.187(0.390)$ \\
\hline Two or more children aged $0-9$ years & $0.096(0.295)$ & $0.113(0.317)$ & $0.125(0.331)$ & $0.125(0.331)$ \\
\hline
\end{tabular}




\begin{tabular}{|c|c|c|c|c|}
\hline Married & $0.711(0.453)$ & $0.760(0.427)$ & $0.768(0.422)$ & $0.793(0.406)$ \\
\hline Age $<25$ & $0.150(0.357)$ & $0.062(0.242)$ & $0.130(0.337)$ & $0.028(0.165)$ \\
\hline $25<=$ age $<35$ & $0.268(0.443)$ & $0.249(0.433)$ & $0.296(0.457)$ & $0.273(0.446)$ \\
\hline $35<=$ age $<45$ & $0.263(0.441)$ & $0.289(0.454)$ & $0.296(0.457)$ & $0.318(0.466)$ \\
\hline $45<=$ age $<55$ & $0.203(0.403)$ & $0.251(0.434)$ & $0.186(0.389)$ & $0.261(0.439)$ \\
\hline $55<=$ age & $0.116(0.320)$ & $0.149(0.356)$ & $0.091(0.288)$ & $0.120(0.326)$ \\
\hline No of rooms per adult in household & $4.220(1.588)$ & $4.233(1.567)$ & $4.300(1.648)$ & $4.424(1.568)$ \\
\hline No of children aged $0-2$ years & $0.098(0.309)$ & $0.123(0.357)$ & $0.137(0.369)$ & $0.132(0.354)$ \\
\hline No of children aged $0-2$ years squared & $0.105(0.370)$ & $0.143(0.491)$ & $0.155(0.489)$ & $0.143(0.435)$ \\
\hline 1 adult in household & $0.142(0.349)$ & $0.154(0.361)$ & $0.137(0.344)$ & $0.148(0.356)$ \\
\hline 2 adults in household & $0.616(0.487)$ & $0.657(0.475)$ & $0.674(0.469)$ & $0.659(0.474)$ \\
\hline More than 2 adults in household & $0.242(0.429)$ & $0.189(0.392)$ & $0.189(0.392)$ & $0.193(0.395)$ \\
\hline Other income & $0.021(0.064)$ & $0.028(0.074)$ & $0.014(0.024)$ & $0.019(0.037)$ \\
\hline Spouse's income if present & $\begin{array}{l}84.245 \\
(75.569)\end{array}$ & $\begin{array}{c}112.790 \\
(90.308)\end{array}$ & $\begin{array}{l}171.106 \\
(143.350)\end{array}$ & $\begin{array}{l}206.840 \\
(172.085)\end{array}$ \\
\hline Indicator for spouse present & $0.289(0.453)$ & $0.240(0.427)$ & $0.232(0.422)$ & $0.207(0.406)$ \\
\hline Number of observations & 1116 & 1009 & 999 & 897 \\
\hline
\end{tabular}




\section{IZA Discussion Papers}

\begin{tabular}{|c|c|c|c|c|}
\hline No. & Author(s) & Title & Area & Date \\
\hline 846 & $\begin{array}{l}\text { D. de la Croix } \\
\text { F. Docquier }\end{array}$ & $\begin{array}{l}\text { Diverging Patterns of Education Premium and } \\
\text { School Attendance in France and the US: A } \\
\text { Walrasian View }\end{array}$ & 6 & $08 / 03$ \\
\hline 847 & B. R. Chiswick & $\begin{array}{l}\text { Jacob Mincer, Experience and the Distribution of } \\
\text { Earnings }\end{array}$ & 1 & $08 / 03$ \\
\hline 848 & $\begin{array}{l}\text { A. Chevalier } \\
\text { G. Conlon }\end{array}$ & Does It Pay to Attend a Prestigious University? & 6 & $08 / 03$ \\
\hline 849 & W. Schnedler & Traits, Imitation, and Evolutionary Dynamics & 5 & $08 / 03$ \\
\hline 850 & $\begin{array}{l}\text { S. P. Jenkins } \\
\text { L. Osberg }\end{array}$ & $\begin{array}{l}\text { Nobody to Play with? The Implications of } \\
\text { Leisure Coordination }\end{array}$ & 5 & $08 / 03$ \\
\hline 851 & J. D. Angrist & $\begin{array}{l}\text { Treatment Effect Heterogeneity in Theory and } \\
\text { Practice }\end{array}$ & 6 & $08 / 03$ \\
\hline 852 & $\begin{array}{l}\text { A. Kugler } \\
\text { M. Kugler }\end{array}$ & $\begin{array}{l}\text { The Labor Market Effects of Payroll Taxes in a } \\
\text { Middle-Income Country: Evidence from } \\
\text { Colombia }\end{array}$ & 1 & $08 / 03$ \\
\hline 853 & $\begin{array}{l}\text { I. Ekeland } \\
\text { J. J. Heckman } \\
\text { L. Nesheim }\end{array}$ & Identification and Estimation of Hedonic Models & 6 & $08 / 03$ \\
\hline 854 & $\begin{array}{l}\text { A. Ferrer-i-Carbonell } \\
\text { B. M. S. Van Praag }\end{array}$ & Income Satisfaction Inequality and Its Causes & 3 & $08 / 03$ \\
\hline 855 & $\begin{array}{l}\text { B. Irlenbusch } \\
\text { D. Sliwka }\end{array}$ & $\begin{array}{l}\text { Career Concerns in a Simple Experimental } \\
\text { Labour Market }\end{array}$ & 1 & $08 / 03$ \\
\hline 856 & D. Sliwka & $\begin{array}{l}\text { Management Incentives, Signaling Effects and } \\
\text { the Costs of Vertical Integration }\end{array}$ & 1 & $08 / 03$ \\
\hline 857 & $\begin{array}{l}\text { M. Francesconi } \\
\text { A. Muthoo }\end{array}$ & An Economic Model of Child Custody & 3 & $08 / 03$ \\
\hline 858 & C. U. Chiswick & $\begin{array}{l}\text { History of Historical Statistics of the United } \\
\text { States }\end{array}$ & 7 & $08 / 03$ \\
\hline 859 & R. Fahr & $\begin{array}{l}\text { Loafing or Learning? The Demand for Informal } \\
\text { Education }\end{array}$ & 5 & $08 / 03$ \\
\hline 860 & $\begin{array}{l}\text { J. Bonke } \\
\text { N. Datta Gupta } \\
\text { N. Smith }\end{array}$ & $\begin{array}{l}\text { Timing and Flexibility of Housework and Men } \\
\text { and Women's Wages }\end{array}$ & 5 & $08 / 03$ \\
\hline
\end{tabular}

An updated list of IZA Discussion Papers is available on the center's homepage www.iza.org. 